\title{
Q or R Factor Analysis for Subjectiveness Measurement in Consumer Behavior? A Study Case on Durable Goods Buying Behavior in Romania
}

\author{
Manuela Rozalia Gabor ${ }^{1, *(D)}$ and Nicoleta Cristache ${ }^{2}$ \\ 1 Economic Sciences Department, Faculty of Economics and Law, "George Emil Palade" University of \\ Medicine, Pharmacy, Sciences and Technology of Târgu Mures, 540142 Târgu Mureș, Romania \\ 2 Faculty of Economics and Business Administration, "Dunărea de Jos" University of Galati, \\ 800008 Galati, Romania; nicoleta.cristache@ugal.ro \\ * Correspondence: manuela.gabor@umfst.ro
}

Citation: Gabor, M.R.; Cristache, N. $\mathrm{Q}$ or R Factor Analysis for

Subjectiveness Measurement in Consumer Behavior? A Study Case on Durable Goods Buying Behavior in Romania. Mathematics 2021, 9, 1136 https://doi.org/10.3390/math9101136

Academic Editor: Mihaela Paun

Received: 20 April 2021

Accepted: 14 May 2021

Published: 17 May 2021

Publisher's Note: MDPI stays neutral with regard to jurisdictional claims in published maps and institutional affiliations.

Copyright: (c) 2021 by the authors. Licensee MDPI, Basel, Switzerland. This article is an open access article distributed under the terms and conditions of the Creative Commons Attribution (CC BY) license (https:// creativecommons.org/licenses/by/ $4.0 /)$.

\begin{abstract}
The complexity of consumer behavior requires new research methods to overcome the limitations of conventional evident-based research. The aim of this paper is the comparison between two types of factor analyses, $Q$ and $R$ (PCA and cluster analysis) for subjectiveness measurement in the case of durable goods buying behavior in Romanian households with different levels of education and occupancy. Our study explores different subjective patterns of stimulus of 30 statements (Qsample) by 30 Romanian households (P-sample) using the Q-sort method for collecting data. For the Q-sample inputs, results from the literature were used. Based on the $30 \mathrm{Q}$-sorts, we discovered four factors for both $\mathrm{Q}$ and $\mathrm{R}$ factor analysis, mostly different according to specific results from different methods. For the Q method, we used the labels "pragmatic", "modern", "traditionalist", and "innovator. For R factor analysis and cluster, we used "traditional Romanian brands", "real needs and power purchasing", "sceptic versus optimistic subjectiveness", and "negative subjectiveness". This paper suggests the $Q$ methodology as a structured and transparent approach to consumer behavior research by combining the in-depth subjectivity of qualitative methods and statistical rigor of factor analysis to identify groups in consumers. The research provides useful suggestions for selecting and approaching target consumer segments in the Romanian durable goods industry.
\end{abstract}

Keywords: factor analysis; Q methodology; subjectivity; Q-sort; P-sample; PCA; cluster analysis; Varimax rotation; durable goods; Romanian households

\section{Introduction and Short Literature Review (Q Factor Analysis)}

The complexity of consumer buying behavior requires new research methods to overcome the limitations of conventional evident-based research [1]. The research provides useful suggestions for selecting and approaching target consumer segments in the Romanian durable goods industry. The $\mathrm{Q}$ methodology is used to map the opinions of people [2], in our case, the head of households, and to explore distinct subjective perspective within a group [3].

The Romanian market for durable goods has many particularities, including the Veblenian behavior of consumers for these goods, the low level of endowment of households with durable goods, a country with a transition economy, being an ex-communist country, and being a European Union member since 2007. Some of these features and particularities are as follows [4-13]:

- A total of $42 \%$ of Romanian households bought durable goods with loans, based on Romanian government politics to increase the household's endowment and to accept loans only with identity cards.

- Only 9\% of households made acquisitions for increasing the family, with the majority having a Veblenian behavior. 
- A significant percentage (34\%) still trusts Romanian brands (e.g., Arctic), but 54\% prefer foreigner brands.

- Half of the households (48.3\%) will buy durable goods in the near future.

- Romanian households manage to buy goods but with restrictions in other areas; this means a low level of purchasing power.

- The price is the most important criterion when buying durable goods.

- A total of $25 \%$ of households have second-hand durable goods.

All the abovementioned features of the Romanian market of durable goods justify this analysis of the subjectiveness for Romanian buying behavior.

The aim of this paper is to use applied research to compare between two types of factor analyses, $Q$ factor analysis ( $Q$ methodology) and $\mathrm{R}$ factor analysis (principal component analysis) for subjectiveness measurement in the case of durable goods buying behavior in Romanian households with different levels of education and occupancy.

In this section, we present a short literature review of the methods that use and we insist on $\mathrm{Q}$ factor analysis considering that $\mathrm{R}$ factor analysis is a well-known method in consumer behavior research.

Originating in the discipline of psychology, $\mathrm{Q}$ methodology remains a relatively unknown and underutilized technique across other disciplines [14]. The basic concept of $Q$ methodology is the psychological concept of operant subjectivity proposed by Stephenson, with an important combination of both qualitative [15] and statistical approaches [14,16-19], which allows us to clarify various competing consumer perspectives and opinions [3] on durable goods market. The parameters of consumer behavior refer to psychological processes such as motivation, perceptions, attitude, etc. [15]. It is also a by person factor analysis [20-23]. The 30 participants (namely P-sample) in the study rank-ordered the 30 statements (namely Q-sample) based on their perceptions and opinions and gave us the opportunity to study them systematically [24].

Unlike a normal factor analysis [25], the $\mathrm{Q}$ factor analysis correlates people with respect to their perception [26] across a sample of variables [27]. PCA and cluster analysis has many applications for marketing data and consumer behavior research [28].

The graphical abstract of this research design is presented in Figure 1 with the specific elements of the $\mathrm{Q}$ factor analysis: the P-sample; the molecular hypothesis for the Q-sorts and output of the methods; and the four final factors as presented in Sections 3 and 4 of the paper, which present the detailed results and discussion for the outputs of the methods.

There are no comparative studies for these methods, and a few papers have analyzed home purchase from a subjective perspective [29,30] using a cross-sectional approach [31] and major reporting gaps among $Q$ methodology publications [19]. There are no studies regarding subjectiveness in consumer behavior or buying decision for durable goods in Romania. To fill this research gap, this study is the first to compare $Q$ and $R$ factor analyses for subjectiveness measurements. It contributes to the existing theory and practice using these methods to examine the subjectiveness of consumer behavior research: experiential consumption in everyday life and consumer perceived value. 


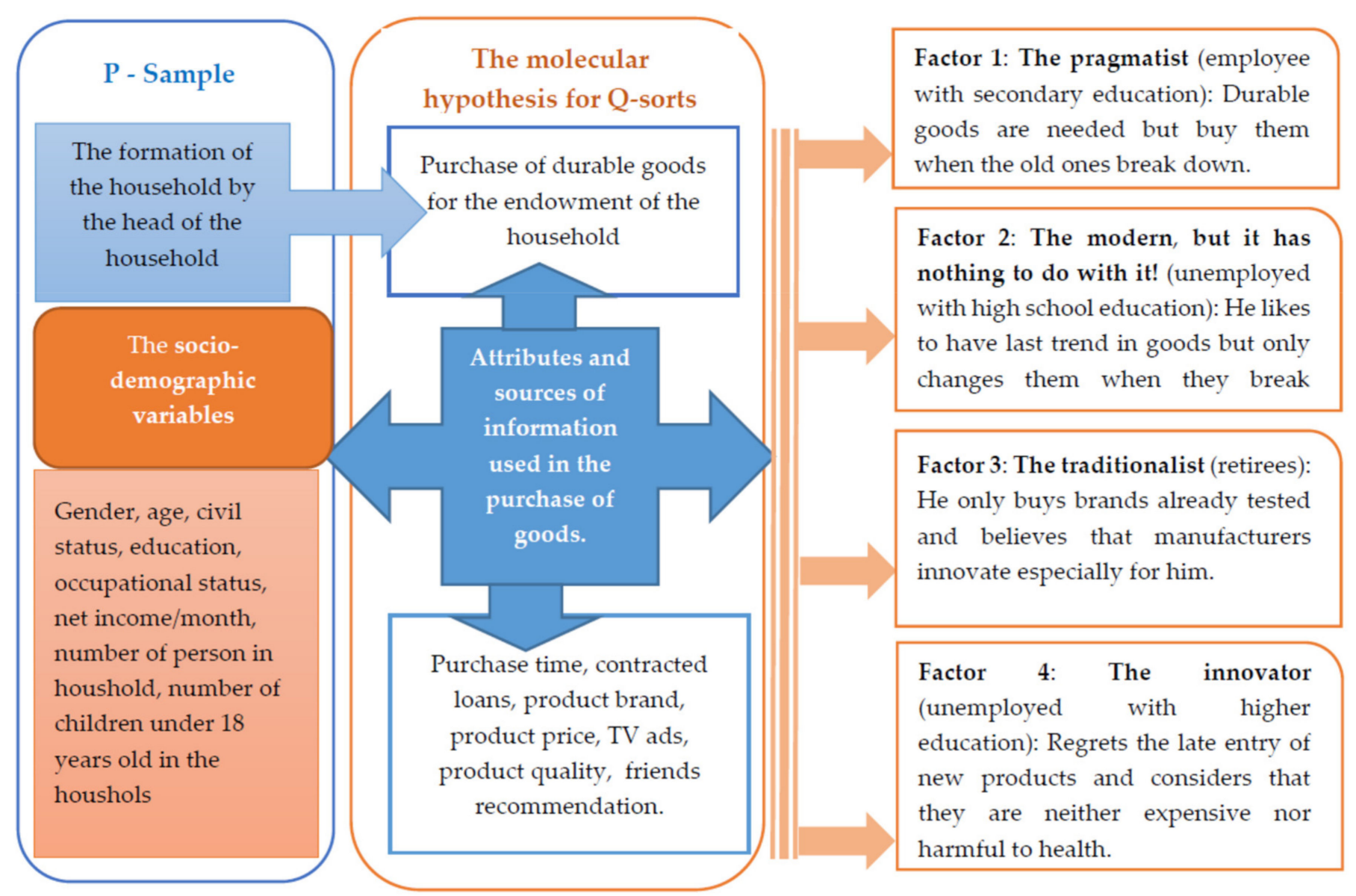

Figure 1. The graphical abstract of the research.

\section{Materials and Methods}

For measuring of subjectiveness in consumer behavior and decisions to buy durable goods, in Romania, we applied, for an objective comparison, two types of factor analysis: $\mathrm{Q}$ factor analysis (known as Q methodology) and R factor analysis, also known as PCA (Principal Component Analysis) and cluster analysis. For both methods, we used Varimax rotation with Kaiser normalization. The Varimax rotation from the PQ Method software has the same role as in $\mathrm{R}$ factor analysis: to maximize the variance of the first extracted factors.

The mathematical model of factor analysis (PCA) assumes that the data subject to analysis are in fact the result of the action of unobserved factors that can be identified and analyzed and has the following form (in the case of standardized variables) [28]:

$$
X_{i}=A_{i 1} F_{1}+A_{i 2} F_{2}+A_{i 3} F_{3}+\ldots+A_{i n} F_{\mathrm{n}}+V_{i} U_{i}
$$

where

- $\quad X i$-variable $i$ from a model and standardized,

- $\quad$ Aij-a standardized multiple regression coefficient of the variable $i$ for common factor $j$ (known as factor loading),

- $\quad F j$ - a common factor (known as factor score),

- $\quad V i$-a standardized multiple regression coefficient of the variable $i$ for unique factor $i$, and

- $\quad n$-number of common factors.

The PCA method differs from basic factor analyses in two major aspects: the calculations of the distances between points and the formula for transforming the terms [32]. 
Equation (2) is the calculation for basic factor analysis, and Equation (3) is the calculation for PCA:

$$
\begin{aligned}
& x_{i j}^{\prime}=\frac{x_{i j}-\bar{x}_{j}}{\sigma_{j}} \\
& x_{i j}^{\prime \prime}=\frac{x_{i j}-\bar{x}_{j}}{\sqrt{n} * \sigma_{j}}
\end{aligned}
$$

$\mathrm{R}$ factor analysis uses the PCA method for calculations, and $Q$ factor analysis use the method of Thurstone's centroid analysis [33]. The final step of the $Q$ methodology is the calculation of the categorical average score for each factor [34] with Equation (4). An important indicator in $\mathrm{Q}$ methodology is the composite fidelity [11] with a value bigger than 0.8. The Steven R Brown formula for composite fidelity is presented in Equation (5) [35].

$$
z_{c}=\frac{\sum_{i=1}^{n c}\left|z_{i}\right|}{n_{c}}
$$

where

- $z_{\mathrm{i}}=$ the $\mathrm{Z}$ score of the statement,

- $c=$ the category, and

- $n_{c}=$ the number of the statements from category c.

$$
r_{x x}=\frac{0.80 * p}{1+(p-1) * 0.80}
$$

where

- $\quad r_{x \mathrm{x}}=$ fidelity coefficient and

- $\quad p=$ the number of subjects which define that factor.

The $Q$ methodology used two important indicators for [35]: the standard error of factorial scores-Equation (6) - and the standard error of differences into normalized factorial scores-Equation (7).

$$
\begin{gathered}
S E_{x}=\sigma_{x} * \sqrt{1-r_{x x}} \\
S E D_{x-z}=\sqrt{S E_{x}^{2}+S E_{y}^{2}}
\end{gathered}
$$

where

- $S E x=$ standard error of the factorial scores for factor $X$ and

- $\sigma x=$ standard deviation of forced distribution imposed in the structure of the Q-sort.

The data were collected in May 2019 based on the Q-sorts with the distribution $(-4$ $-3-2-10+1+2+3+4)$ described in Figure 2 using $(+4)$ for the most important and $(-4)$ for the most unimportant. The Q-sort was conducted in person [36]. The Q-sample has 30 sentences detailed in the Section 3.1. of the paper. The P-sample has 30 household heads [31] from Tîrgu Mures with respect to the national distribution of households at the urban level, being a representative sample. The structure and sociodemographic characteristics of the P-sample are presented in Table 1. One of the most striking features of the $\mathrm{Q}$ methodology is that the research is limited to small samples $[33,35]$. The objectives for which the Q methodology is used are achieved perfectly and with small samples in the conditions in which the diversity of opinions is ensured by the researcher [33,35]. Thus, the selection of individuals participating in the study should be made not based on a random algorithm; in contrast, it should have a careful selection basis of subjects likely to bring more subjectivity and new opinions in the study. The diversity of opinions is the objective subsumed by the principle of theoretical saturation for this method. Sampling, according to the classical social sciences, has no significance for the Q methodology [33,35]. The Q methodology uses four specific concepts: P-sample (subjects of the study case); Q-sorts (for collecting data); Q-sample (statements of the Q-sorts); and the molecular 
hypothesis [35], namely, the molecular assumptions of $\mathrm{Q}$ methodology. Moreover, in the case of $\mathrm{Q}$ methodology, we refer to inductive (exploratory) inference and deductive inference (ante hoc hypotheses devised by the researcher) of the results.

Table 1. The structure of the P-sample.

\begin{tabular}{|c|c|c|}
\hline Characteristics & & Frequencies (\%) \\
\hline \multirow[t]{2}{*}{ Gender } & Male & $17(57 \%)$ \\
\hline & Female & $13(43 \%)$ \\
\hline \multirow{5}{*}{$\begin{array}{l}\text { Number of persons in the } \\
\text { household }\end{array}$} & 1 person & $3(10 \%)$ \\
\hline & 2 persons & $8(27 \%)$ \\
\hline & 3 persons & $8(27 \%)$ \\
\hline & 4 persons & $9(29 \%)$ \\
\hline & 5 persons & $2(7 \%)$ \\
\hline \multirow{3}{*}{$\begin{array}{l}\text { Number of children under } 18 \\
\text { years old in the household }\end{array}$} & 1 child & $22(73 \%)$ \\
\hline & 2 children & $6(20 \%)$ \\
\hline & 3 children & $2(7 \%)$ \\
\hline \multirow{5}{*}{ Age group } & Under 24 years & $2(7 \%)$ \\
\hline & 25-34 years & $4(13 \%)$ \\
\hline & $35-49$ years & $13(43 \%)$ \\
\hline & 50-64 years & $9(30 \%)$ \\
\hline & More 65 years & $2(7 \%)$ \\
\hline \multirow{3}{*}{ Civil status } & Unmarried & $4(13 \%)$ \\
\hline & Married & $24(80 \%)$ \\
\hline & Divorced/Widowed & $2(7 \%)$ \\
\hline \multirow{11}{*}{ Occupational status } & Business owner & \\
\hline & Retired & $4(13 \%)$ \\
\hline & Self employed & $7(24 \%)$ \\
\hline & Employee with university & $2(7 \%)$ \\
\hline & degree & $4(13 \%)$ \\
\hline & Employee with secondary & $7(24 \%)$ \\
\hline & education & $1(3 \%)$ \\
\hline & Manager & $3(10 \%)$ \\
\hline & Unemployed & $1(3 \%)$ \\
\hline & Household & $1(3 \%)$ \\
\hline & Unqualified worker & \\
\hline \multirow{3}{*}{ Education } & Gymnasium/Primary & $1(3 \%)$ \\
\hline & education & $22(74 \%)$ \\
\hline & $\begin{array}{l}\text { Secondary education } \\
\text { College/university }\end{array}$ & $7(23 \%)$ \\
\hline \multirow{3}{*}{ Net income/month } & $<1350$ lei & $5(17 \%)$ \\
\hline & 1350-3500 lei & $21(70 \%)$ \\
\hline & $<3500$ lei & $4(13 \%)$ \\
\hline
\end{tabular}




\begin{tabular}{|c|c|c|c|c|c|c|c|c|}
\hline \multicolumn{9}{|c|}{$Q$ sort values } \\
\hline-4 & -3 & -2 & -1 & 0 & +1 & +2 & +3 & +4 \\
\hline \multicolumn{9}{|c|}{ Factor 1 - Pragmatic: employee with secondary education } \\
\hline 7 & 18 & 8 & 1 & 5 & 2 & 6 & 3 & $4^{*}$ \\
\hline & 30 & 10 & 11 & 9 & 15 & 23 & $14 *$ & \\
\hline & & $12 *$ & 13 & 21 & 16 & $28 *$ & & \\
\hline & & 26 & 20 & 27 & 17 & 29 & & \\
\hline & & & 22 & 19 & 24 & & & \\
\hline & & & & 25 & & & & \\
\hline
\end{tabular}

Factor 2 - Modern but it has nothing! unemployed with secondary

\begin{tabular}{|c|c|c|c|c|c|c|c|c|}
\hline $24 *$ & 27 & 5 & 1 & 2 & 8 & 7 & 3 & 18 \\
\hline & 29 & 6 & 14 & 11 & 20 & 10 & $9 *$ & \\
\hline & & 25 & 15 & 13 & 21 & 12 & & \\
\hline & & 28 & 16 & 17 & 23 & 22 & & \\
\hline & & & 4 & 19 & 30 & & & \\
\hline & & & & 26 & & & & \\
\hline
\end{tabular}

\begin{tabular}{|c|c|c|c|c|c|c|c|c|}
\hline \multicolumn{9}{|c|}{ Q sort values } \\
\hline-4 & -3 & & & & 0 & +1 & $+2+3$ & +4 \\
\hline \multicolumn{9}{|c|}{ Factor 3 - Traditional: retired } \\
\hline \multirow[t]{6}{*}{5} & $19 *$ & 4 & 1 & 8 & 6 & 12 & 2 & $13^{*}$ \\
\hline & $21^{*}$ & 7 & 14 & 9 & 20 & 15 & $11^{*}$ & \\
\hline & & 10 & 18 & 17 & 29 & 16 & & \\
\hline & & 27 & 26 & 22 & 30 & 24 & & \\
\hline & & & 28 & 23 & 3 & & & \\
\hline & & & & 25 & & & & \\
\hline
\end{tabular}

\begin{tabular}{|c|c|c|c|c|c|c|c|c|}
\hline \multicolumn{2}{|c|}{15} & 8 & 2 & 1 & 10 & 7 & 15 & 22 \\
\hline & 26 & $17 *$ & 4 & 6 & 12 & $19 *$ & 18 & \\
\hline & & 29 & 5 & 9 & 16 & 24 & & \\
\hline & & 28 & 20 & 11 & 23 & 3 & & \\
\hline & & & 30 & 21 & 27 & & & \\
\hline & & & & 25 & & & & \\
\hline
\end{tabular}

Figure 2. The Q-sort values for each of extracted four factors. (Note: ${ }^{*} p$-value $<0.01$ ).

By ensuring the representativeness of the P-sample, in fact, within the $\mathrm{Q}$ methodology, the heterogeneity of opinions regarding the statements used in the Q-sample is ensured; this aspect is nothing more than a sample of opinions and perceptions.

For molecular hypotheses specific for the $\mathrm{Q}$ methodology and for the statements of Q-sorts, we used research results for durable goods market in Romania made by the author in the period 2008-2018 [4-13,28].

The $\mathrm{Q}$ methodology has as a fundamental hypothesis that the items are completely interdependent [33] on the 30 statements from Q-sorts and that it has as a starting point a correlation matrix similar to $\mathrm{R}$ factor analysis, but for subjects (P-sample) rather than for variables, as presented in Figure A1-from Appendix A.

For Q methodology, the free PQ Method software (http:/ /schmolck.org/qmethod/) [37] was used [16,18,20,38-41]. For PCA and cluster analysis, SPSS 23.0 statistical software was used. A free trial version of GraphPad Prism 9.1 (https:/ /www.graphpad.com/) [42] was used for graphical representations of the $Q$ and $R$ factor analyses, the free site www.visme.com was used [43] for the Venn diagram, and Microsoft Excel was used for the heat map.

\section{Results}

\subsection{Results for $Q$ Factor Analysis (Q Methodology)}

Following the first step of any factor analysis, in our correlation matrix (Figure A1from Appendix A), there are

- Preponderant negative correlations, which mean opposite perceptions, subjectiveness, and opinions in the P-sample between, for example, subjects 5-a retired person with secondary education - and 17-a business owner with secondary education;

- Preponderant positive correlations, with, for example, all seven employees with secondary education having similar opinions for the rest of the P-sample; and medium positive correlations.

From the first extraction using Varimax rotation from the PQ Method software, the seven resultant factors (Figure 3) explained $47 \%$ of total variance. Only five factors have an eigenvalue greater than 1 and explain $44 \%$ of total variance. Finally, the PQ Method software retains only four factors. 


\begin{tabular}{|c|c|c|c|c|c|c|c|}
\hline & 1 & 2 & 3 & Factors & 5 & 6 & 7 \\
\hline 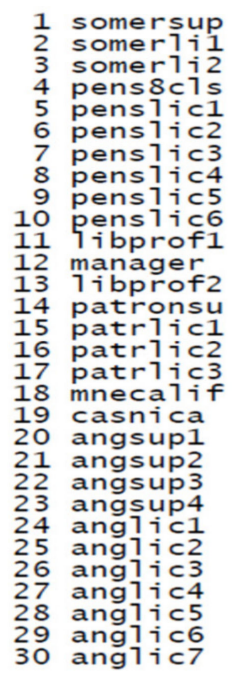 & $\begin{array}{l}0.2204 \\
0: 34422 \\
0: 7315 \\
0: 0419 \\
0: 1084 \\
0: 0848 \\
0: 3949 \\
0: 4624 \\
0: 4708 \\
0: 4884 \\
0: 3446 \\
0: 1249 \\
0: 4515 \\
0: 4825 \\
0: 2834 \\
0: 4557 \\
-0.1167 \\
0: 5631 \\
0: 1805 \\
0: 6215 \\
0: 5375 \\
0: 3445 \\
0: 6963 \\
0: 4007 \\
0: 3767 \\
0: 7315 \\
0: 0958 \\
0: 37701 \\
0: 7385 \\
0.5011\end{array}$ & $\begin{array}{r}0.1926 \\
0: 2500 \\
0: 1157 \\
-0: 1226 \\
-0: 2907 \\
0: 1357 \\
-0: 4588 \\
-0: 6299 \\
0: 1909 \\
0: 1771 \\
0: 4110 \\
0: 0829 \\
0: 0041 \\
0: 2987 \\
-0: 4252 \\
-0: 1566 \\
-0: 2940 \\
-0: 5371 \\
-0: 1125 \\
-0.0873 \\
0: 2139 \\
0: 4126 \\
-0: 2577 \\
0: 0225 \\
0: 3561 \\
0: 1157 \\
0: 0454 \\
0: 3638 \\
-0: 1102 \\
0: 0318\end{array}$ & 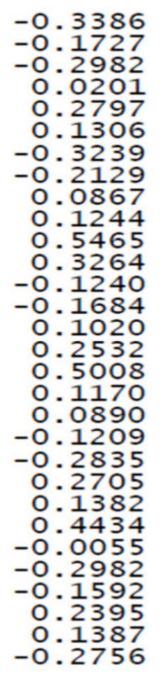 & 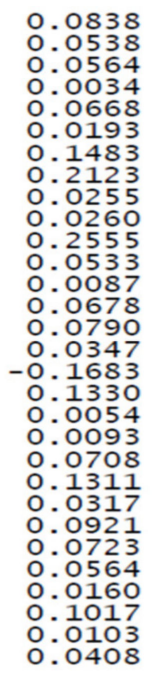 & 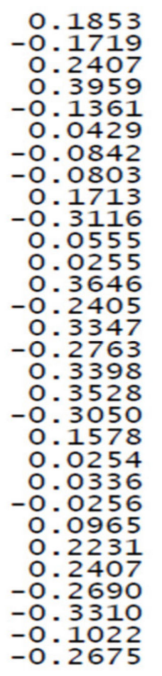 & 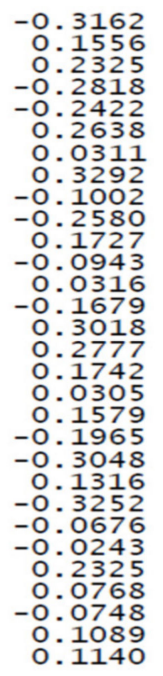 & 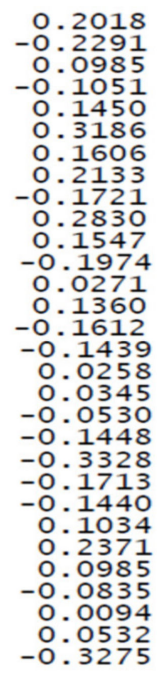 \\
\hline $\begin{array}{l}\text { eigenvalues } \\
\text { \% exp1.var. }\end{array}$ & $\begin{array}{r}5.8359 \\
19\end{array}$ & 2.3421 & 1.9487 & 0.2651 & 1.5631 & 1.2144 & 0.9625 \\
\hline
\end{tabular}

Figure 3. Unrotated factors matrix.

From Figure 2, it can be observed that factor 1 and factor 4 are positively correlated with all subjects except subject 17-a business owner with secondary education. For all factors, there are subjects with different variations between them. In Figure 4, the matrix of the cumulated communalities of the seven factors extracted initially is presented.

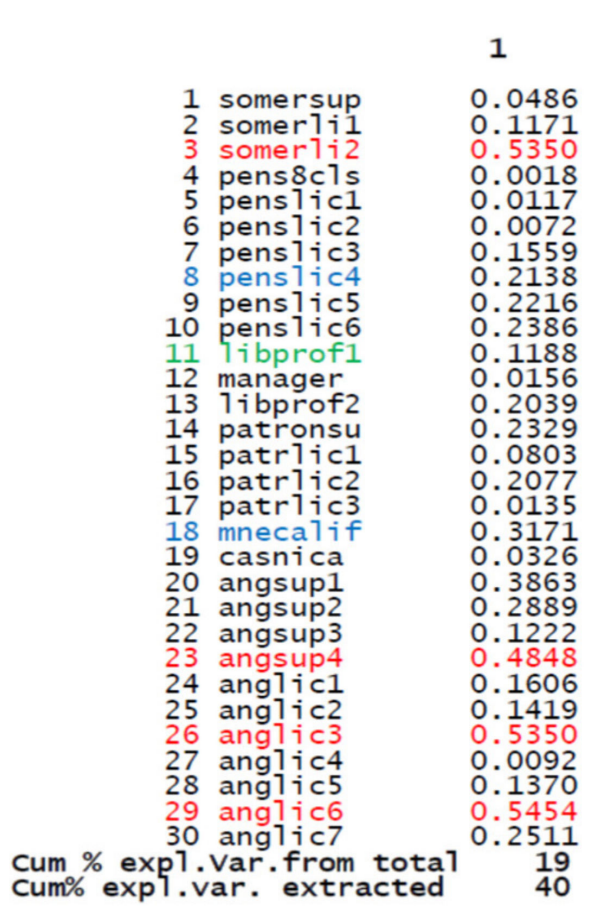

2.
0.0857
0.1796
0.5484
0.0168
0.0962
0.0256
0.3664
0.6106
0.2581
0.2699
0.2877
0.0225
0.2039
0.3221
0.2611
0.2322
0.0999
0.6056
0.0452
0.3939
0.3347
0.2924
0.5512
0.1611
0.2687
0.5484
0.0112
0.2693
0.5575
0.2521

0.57

\begin{tabular}{cc}
\multicolumn{2}{c}{ Factors } \\
0.2003 & 0.2073 \\
0.2094 & 0.2123 \\
0.6373 & 0.6405 \\
0.0172 & 0.0172 \\
0.1745 & 0.1789 \\
0.0427 & 0.0430 \\
0.4713 & 0.4933 \\
0.6560 & 0.7010 \\
0.2656 & 0.2662 \\
0.2854 & 0.2861 \\
0.5863 & 0.6516 \\
0.1290 & 0.1319 \\
0.2192 & 0.2193 \\
0.3504 & 0.3550 \\
0.2715 & 0.2777 \\
0.2963 & 0.2975 \\
0.3507 & 0.3790 \\
0.6193 & 0.6369 \\
0.0531 & 0.0532 \\
0.4085 & 0.4086 \\
0.4150 & 0.4201 \\
0.3656 & 0.3827 \\
0.5703 & 0.5713 \\
0.3576 & 0.3661 \\
0.2687 & 0.2740 \\
0.6373 & 0.6405 \\
0.0366 & 0.0368 \\
0.3267 & 0.3370 \\
0.5768 & 0.5769 \\
0.3281 & 0.3297 \\
34 & 35 \\
772 & \\
&
\end{tabular}

5
0.2416
0.2418
0.6984
0.1740
0.1974
0.0449
0.5004
0.7075
0.2956
0.3832
0.6546
0.1325
0.3523
0.4129
0.3898
0.3738
0.4945
0.7614
0.1462
0.4335
0.4207
0.3839
0.5720
0.3754
0.3237
0.6984
0.1092
0.4465
0.5874
0.4013

0.85

$\begin{array}{cc}6 & 7 \\ 0.3416 & 0.3823 \\ 0.2660 & 0.3185 \\ 0.7525 & 0.7622 \\ 0.2534 & 0.2644 \\ 0.2561 & 0.2771 \\ 0.1144 & 0.2159 \\ 0.5014 & 0.5272 \\ 0.8159 & 0.8613 \\ 0.3056 & 0.3352 \\ 0.4498 & 0.5298 \\ 0.6845 & 0.7084 \\ 0.1414 & 0.1804 \\ 0.3533 & 0.3540 \\ 0.4411 & 0.4596 \\ 0.4809 & 0.5069 \\ 0.4510 & 0.4717 \\ 0.5248 & 0.5255 \\ 0.7623 & 0.7635 \\ 0.1712 & 0.1740 \\ 0.4721 & 0.4931 \\ 0.5136 & 0.6244 \\ 0.4012 & 0.4305 \\ 0.6778 & 0.6985 \\ 0.3800 & 0.3907 \\ 0.3243 & 0.3805 \\ 0.7525 & 0.7622 \\ 0.1151 & 0.1221 \\ 0.4521 & 0.4522 \\ 0.5992 & 0.6020 \\ 0.4143 & 0.5215 \\ 444 & 47 \\ 094 & 100\end{array}$

Figure 4. Matrix of the cumulated communalities of the seven factors extracted initially.

We marked with colors all of the subjects associated with each factor. For those subjects with low values of communalities (subject 4-retired with gymnasium education), a relatively unique answer can be considered, which was strongly different from the answers of other subjects. Another aspect from Figure 4 is related to the horizontal sum of the communalities (the column of factor 7), which represents the sum of variations of a 
factor for the same subject and provides answers about the percentage of common answers of that subject with all seven factors. It sustains that subjects with low communalities do not align with the general opinions explained by the seven factors for the 30 subjects.

The angles of rotation (six two-dimensional rotations) used between the four factors are presented in Figure 5a. In Figure 5b,c, the distribution of the subjects are presented on a two-dimensional space for factors 1 and 2 (Figure $5 b$ ) and for factors 3 and 4 (Figure 5c), with the points representing the 30 Q-sorts (the opinions) completed by the subjects of the P-sample.

\begin{tabular}{ccc} 
FACTOR & \multicolumn{2}{c}{ FACTOR } \\
1 & 2 & -50. \\
1 & 2 & -15. \\
3 & 4 & 45. \\
3 & 4 & -10 \\
3 & 4 & -10 \\
3 & 4 & 45.
\end{tabular}

(a)

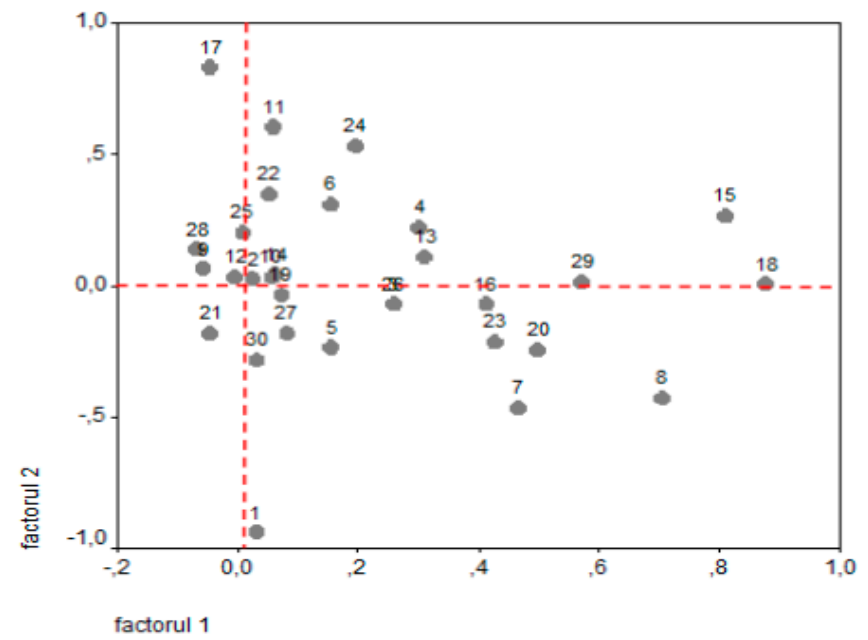

(b)

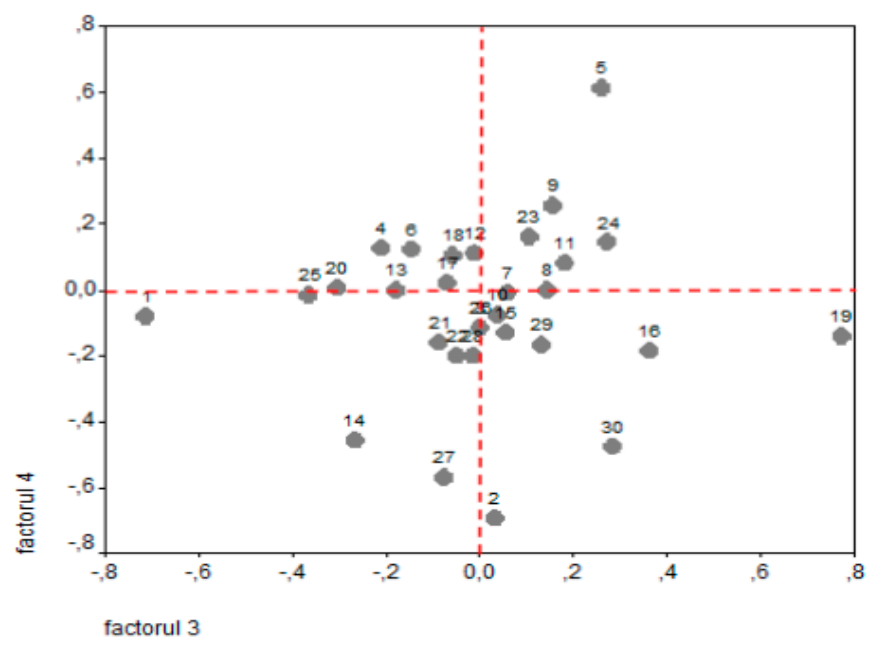

(c)

Figure 5. Angles of rotation and distribution of the subjects on the extracted factors (a) The angles of rotation; (b) The distribution of the subjects on factors 1 and 2; (c) The distribution of the subjects on factors 3 and 4 .

Figure $5 \mathrm{~b}$ shows that all subjects are well represented on the first two factors. Most of them, following the rotations performed, are "pure" cases, strongly polarized on the factorial axis. Subjects 9, 12, 10, 14, 3, 26, 28, 29 18, and 16 are found on factorial axis 1 . Subjects $25,12,30$, and 1 are found on factorial axis 2 . It is also observed that, although characterized by the variance in the second factor, subjects 17-an employer with high school education - and 1-unemployed with higher education-have opposite opinions. Additionally, subjects 28 (employee with high school education), 21 (employee with higher education), and 9 (retired with high school education), are positioned on factorial axis 1 in a negative plan and form different opinions, opposite to the rest of the subjects characterized by the variance in factor 1 . By the graphical representation of the two factors the separate opinions of subjects 17 and 18, and 1 and 29 are confirmed by the data included in the initial correlation matrix (Figure A1-from Appendix A). 
Figure $5 c$ shows that the number of pure cases is better defined, with factor 3 explaining, except for subject 1 - unemployed with higher education — and subject 19, the opinions of all other subjects in the study. Additionally, in the case of factor 4, there are subjects who have conflicting opinions with others: subjects 2, 27, 14, and 30 . The best represented subject in the positive plane formed by the two factors is subject 5 . In Figure A2-from Appendix A, the location of the subjects in space generated by the four factors (matrix of factors) is presented, with " $\mathrm{X}$ " indicating the subjects who define and form each factor.

The results from Figure A2-from Appendix A show only the subjects' coordinates, but for a better explanation of the similarities and differences of the opinion between subjects, it is necessary to calculate the weights of each defining Q-sort (those marked with an X in Figure A2-from Appendix A) based on the saturation in factors. These results are presented in Table 2. The last column of Table 2 indicates that only factors 2 and 4 are strong groups. Factor 2 groups retired persons and unqualified workers. Factor 4 groups the unemployed with higher education, and the household. The strongest characterization of each factor is marked with red in Table 2.

Table 2. Generating the weights of each Q-sort based on saturations in factors.

\begin{tabular}{|c|c|c|c|c|c|}
\hline Defining Q-Sorts & $S$ (Saturation in Factors) & $w=\frac{s}{1-s^{2}}$ & $\left|\frac{1}{w_{\max }}\right|$ & $\boldsymbol{w}\left|\frac{1}{w_{\max }}\right|$ & Rounded (x 10) \\
\hline \multicolumn{6}{|c|}{ Factor 1} \\
\hline 24 employee/sec educ & 0.1969 & 0.19 & \multirow[t]{7}{*}{2.60} & 0.49 & 5 \\
\hline 25 employee/sec educ & 0.0094 & 0.01 & & 0.02 & 0 \\
\hline 26 employee/sec educ & 0.2610 & 0.24 & & 0.63 & 6 \\
\hline 27 employee/sec educ & 0.0824 & 0.08 & & 0.21 & 2 \\
\hline 28 employee/sec educ & -0.0670 & -0.07 & & -0.17 & -2 \\
\hline 29 employee/sec educ & 0.5737 & 0.38 & & 1 & 10 \\
\hline 30 employee/sec educ & 0.0320 & 0.03 & & 0.08 & 1 \\
\hline \multicolumn{6}{|c|}{ Factor 2} \\
\hline 7 retired/sec educ & -0.4678 & -0.37 & 2.74 & -1 & -10 \\
\hline 8 retired/sec educ & -0.4298 & -0.35 & & -0.96 & -10 \\
\hline 18 unq worker/gymn & 0.0052 & 0.01 & & 0.01 & 0 \\
\hline \multicolumn{6}{|c|}{ Factor 3} \\
\hline 2 unempl/sec educ & 0.0336 & 0.03 & 13.34 & 0.45 & 4 \\
\hline $27 \mathrm{empl} / \mathrm{sec}$ educ & -0.0754 & -0.07 & & -1.00 & -10 \\
\hline \multicolumn{6}{|c|}{ Factor 4} \\
\hline 1 unempl/higher educ & -0.0823 & -0.08 & 7.24 & -0.59 & -6 \\
\hline 19 household & -0.1410 & -0.14 & & -1 & -10 \\
\hline
\end{tabular}

Note: $\mathrm{S}$ = saturation; $\mathrm{w}$ = weight of each Q-sort, sec educ = secondary education, unq = unqualified, gymn = gymnasium education, empl = employe, unempl = unemployee, higher educ = higher education.

In Table 3, we present the statements included in each factor, normalized, and rounded scores for Q-sorts, and a heat map for the final scores. Red marks all the subjects who agree. Blue marks the subjects who disagree with all four factors. For a better visualization of the final scores for each statement, we made a heat map with the same legend: red for positive/agreement scores and blue for negative/disagreement scores. 
Table 3. The share of statements (Q-sorts) included in each factor, normalized and rounded scores for Q-sorts, and the heat map for final scores.

\begin{tabular}{|c|c|c|c|c|c|c|c|c|c|c|c|c|c|c|}
\hline \multirow{3}{*}{ No } & \multirow{3}{*}{ Statements of the Q-sorts * } & \multirow{3}{*}{ No } & \multicolumn{8}{|c|}{$\begin{array}{l}\text { The Share of Statements (Q-Sorts) Included in } \\
\text { Each of the Four Factors }\end{array}$} & \multicolumn{4}{|c|}{$\begin{array}{c}\text { Normalized and } \\
\text { Rounded Scores for } \\
\text { Q-Sorts }\end{array}$} \\
\hline & & & \multicolumn{8}{|c|}{$\begin{array}{c}\text { Factors and Correspondent Number of } \\
\text { Respondent (P) }\end{array}$} & \multicolumn{4}{|c|}{ Factor Arrays } \\
\hline & & & F1 & $\mathbf{P}$ & F2 & $\mathbf{P}$ & F3 & $\mathbf{P}$ & F4 & $\mathbf{P}$ & F1 & F2 & F3 & F4 \\
\hline 1 & $\begin{array}{l}\text { The sale of durable goods on } \\
\text { "credit only with the identity } \\
\text { card" was a good policy that } \\
\text { led to an increase in the } \\
\text { standard of living of } \\
\text { households }\end{array}$ & 1 & -0.53 & 20 & -0.57 & 20 & -0.76 & 22 & 0.14 & 16 & -1 & -1 & -1 & 0 \\
\hline 2 & $\begin{array}{l}\text { What I always aim when } \\
\text { buying durable goods are the } \\
\text { technical performance and the } \\
\text { energy consumption class, not } \\
\text { the price or discounts granted. }\end{array}$ & 2 & 0.79 & 9 & 0.26 & 15 & 1.52 & 3 & -0.44 & 21 & 1 & 0 & 3 & -1 \\
\hline 3 & $\begin{array}{l}\text { The reason why I buy durable } \\
\text { goods is to increase the needs } \\
\text { of the family, the household }\end{array}$ & 3 & 1.49 & 3 & 1.22 & 3 & 0.29 & 13 & 0.60 & 8 & 3 & 3 & 0 & 1 \\
\hline 4 & $\begin{array}{l}\text { Durable goods are a must in } \\
\text { any household }\end{array}$ & 4 & 2.11 & 1 & -0.84 & 24 & -1.17 & 27 & -0.30 & 20 & 4 & -2 & -2 & -1 \\
\hline 5 & $\begin{array}{c}\text { Romanian brands are } \\
\text { competitive on the market }\end{array}$ & 5 & 0.16 & 13 & -1.14 & 26 & -1.76 & 30 & -0.82 & 23 & 0 & -2 & -4 & -1 \\
\hline 6 & $\begin{array}{c}\text { Durable goods make } \\
\text { household chores easier }\end{array}$ & 6 & 1.21 & 4 & -0.84 & 24 & 0.47 & 10 & 0 & 18 & 2 & -2 & 1 & 0 \\
\hline 7 & $\begin{array}{l}\text { The new technologies for goods } \\
\text { are better for health }\end{array}$ & 7 & -1.81 & 30 & 1.13 & 4 & -0.88 & 24 & 0.82 & 6 & -4 & 2 & -2 & 2 \\
\hline 8 & $\begin{array}{l}\text { I am influenced, in the buying } \\
\text { decision of durable goods, by } \\
\text { TV/ radio/press } \\
\text { advertisements }\end{array}$ & 8 & -0.87 & 25 & 0.80 & 8 & 0.00 & 17 & -0.90 & 24 & -2 & 1 & 0 & -2 \\
\hline 9 & $\begin{array}{l}\text { I like to have the last } \\
\text { generations of durable goods }\end{array}$ & 9 & -0.08 & 14 & 1.68 & 2 & -0.29 & 18 & 0.36 & 13 & 0 & 3 & 0 & 0 \\
\hline 10 & $\begin{array}{l}\text { I buy those brands of durable } \\
\text { goods recommended by the } \\
\text { friends }\end{array}$ & 10 & -0.80 & 24 & 0.84 & 7 & -1.11 & 26 & 0.52 & 10 & -2 & 2 & -2 & 1 \\
\hline 11 & $\begin{array}{c}\text { I buy those brands of durable } \\
\text { goods that I already have in my } \\
\text { household and tested }\end{array}$ & 11 & -0.59 & 22 & 0.53 & 13 & 1.88 & 2 & 0.22 & 14 & -1 & 0 & 3 & 0 \\
\hline 12 & $\begin{array}{c}\text { The brand of the product } \\
\text { always means the quality of the } \\
\text { product }\end{array}$ & 12 & -0.97 & 26 & 0.91 & 5 & 0.82 & 6 & 0.38 & 12 & -2 & 2 & 2 & 1 \\
\hline 13 & $\begin{array}{c}\text { Manufacturers of durable } \\
\text { goods are constantly } \\
\text { innovating to make household } \\
\text { chores easier and to increase } \\
\text { comfort }\end{array}$ & 13 & -0.69 & 23 & -0.27 & 18 & 2.05 & 1 & -1.65 & 29 & -1 & 0 & 4 & -3 \\
\hline 14 & $\begin{array}{c}\text { Durable goods made radiation } \\
\text { harmful to health (microwave } \\
\text { oven, tube monitors, mobile } \\
\text { phones, TVs, etc.) }\end{array}$ & 14 & 1.65 & 2 & -0.60 & 21 & -0.82 & 23 & -2.09 & 30 & 3 & -1 & -1 & -4 \\
\hline 15 & $\begin{array}{c}\text { Romanian durable goods a } \\
\text { more qualitative than imported } \\
\text { one }\end{array}$ & 15 & 0.19 & 12 & -0.62 & 22 & 0.76 & 7 & 1.79 & 2 & 1 & -1 & 2 & 3 \\
\hline
\end{tabular}


Table 3. Cont.

\begin{tabular}{|c|c|c|c|c|c|c|c|c|c|c|c|c|c|c|}
\hline \multirow{3}{*}{ No } & \multirow{3}{*}{ Statements of the Q-sorts * } & \multirow{3}{*}{ No } & \multicolumn{8}{|c|}{$\begin{array}{c}\text { The Share of Statements (Q-Sorts) Included in } \\
\text { Each of the Four Factors }\end{array}$} & \multicolumn{4}{|c|}{$\begin{array}{c}\text { Normalized and } \\
\text { Rounded Scores for } \\
\text { Q-Sorts }\end{array}$} \\
\hline & & & \multicolumn{8}{|c|}{$\begin{array}{c}\text { Factors and Correspondent Number of } \\
\text { Respondent (P) }\end{array}$} & \multicolumn{4}{|c|}{ Factor Arrays } \\
\hline & & & F1 & $\mathbf{P}$ & F2 & $\mathbf{P}$ & F3 & $\mathbf{P}$ & F4 & $\mathbf{P}$ & F1 & F2 & F3 & F4 \\
\hline 16 & $\begin{array}{l}\text { Future purchase of durable } \\
\text { goods depends on the financial } \\
\text { recovery of the household }\end{array}$ & 16 & 0.39 & 11 & -0.30 & 19 & 1.11 & 4 & 0.44 & 11 & 1 & -1 & 2 & 1 \\
\hline 17 & $\begin{array}{c}\text { The late-generations of goods } \\
\text { are far too expensive for my } \\
\text { purchasing power }\end{array}$ & 17 & 0.89 & 8 & 0.05 & 16 & 0.23 & 15 & -1.12 & 26 & 1 & 0 & 0 & -2 \\
\hline 18 & $\begin{array}{l}\text { A high price means a } \\
\text { guaranteed quality }\end{array}$ & 18 & -1.33 & 28 & 1.71 & 1 & -0.47 & 20 & 1.65 & 3 & -3 & 4 & -1 & 3 \\
\hline 19 & $\begin{array}{l}\text { World-renowned brands, } \\
\text { producers of durable goods, } \\
\text { have introduced } \\
\text { late-generation products late in } \\
\text { Romania compared to other EU } \\
\text { countries }\end{array}$ & 19 & -0.23 & 17 & -0.26 & 17 & -1.46 & 28 & 1.05 & 4 & 0 & 0 & -3 & 2 \\
\hline 20 & $\begin{array}{l}\text { The sale of "second-hand" } \\
\text { durable goods has turned } \\
\text { Romanian households into } \\
\text { "Europe's garbage dump". }\end{array}$ & 20 & -0.54 & 21 & 0.57 & 11 & 0.35 & 11 & -0.14 & 19 & -1 & 1 & 1 & -1 \\
\hline 21 & $\begin{array}{l}\text { Reducing the renewal time of } \\
\text { the household with durable } \\
\text { goods is encouraged by } \\
\text { consumers }\end{array}$ & 21 & -0.11 & 15 & 0.61 & 9 & -1.52 & 29 & 0.00 & 18 & 0 & 1 & -3 & 0 \\
\hline 22 & $\begin{array}{l}\text { Imported durable goods are } \\
\text { better than Romanian one }\end{array}$ & 22 & -0.45 & 19 & 0.88 & 6 & 0.29 & 13 & 1.87 & 1 & -1 & 2 & 0 & 4 \\
\hline 23 & $\begin{array}{l}\text { Romanian producers of durable } \\
\text { goods do not know how to } \\
\text { competitively promote their } \\
\text { products on foreign markets }\end{array}$ & 23 & 0.95 & 5 & 0.57 & 11 & 0.18 & 16 & 0.60 & 8 & 2 & 1 & 0 & 1 \\
\hline 24 & $\begin{array}{l}\text { I change the durable goods } \\
\text { when they break down only }\end{array}$ & 24 & 0.79 & 10 & -2.02 & 30 & 1.06 & 5 & 0.82 & 6 & 1 & -4 & 2 & 2 \\
\hline 25 & $\begin{array}{l}\text { I still have old durable goods in } \\
\text { my household (black and white } \\
\text { TV, washing machine, sewing } \\
\text { machine, Dacia car, refrigerator, } \\
\text { stove, etc.) and I still use its }\end{array}$ & 25 & -0.39 & 18 & -1.11 & 25 & 0.23 & 15 & 0.16 & 15 & 0 & -2 & 0 & 0 \\
\hline 26 & $\begin{array}{c}\text { There must be a TV in each } \\
\text { room and each family member } \\
\text { so that there are no } \\
\text { misunderstandings in the } \\
\text { family }\end{array}$ & 26 & -1.16 & 27 & 0.53 & 14 & -0.47 & 20 & -1.27 & 28 & -2 & 0 & -1 & -3 \\
\hline 27 & $\begin{array}{l}\text { I bought most of the durable } \\
\text { goods by installments (at } \\
\text { bank/retailer). }\end{array}$ & 27 & -0.19 & 16 & -1.67 & 29 & -1.06 & 25 & 0.52 & 10 & 0 & -3 & -2 & 1 \\
\hline 28 & $\begin{array}{c}\text { The only reason I buy durable } \\
\text { goods is that the old ones are } \\
\text { broken }\end{array}$ & 28 & 0.91 & 6 & -1.18 & 27 & -0.53 & 21 & -1.27 & 28 & 2 & -2 & -1 & -3 \\
\hline 29 & $\begin{array}{l}\text { A well-known brand of a } \\
\text { durable good is not always a } \\
\text { guarantee of product quality }\end{array}$ & 29 & 0.91 & 7 & -1.45 & 28 & 0.53 & 9 & -1.12 & 26 & 2 & -3 & 1 & -2 \\
\hline 30 & $\begin{array}{l}\text { I don't consider discounted or } \\
\text { feast periods (Christmas, Easter, } \\
\text { etc.) when I buy durable goods }\end{array}$ & 30 & -1.67 & 29 & 0.57 & 12 & 0.53 & 9 & -0.82 & 23 & -3 & 1 & 1 & -1 \\
\hline
\end{tabular}

Note: For all statements of the Q-sort, the research results made by the author in the period 2008-2018 was used [4-13,28]. 
Based on the data from Table 3, we constructed a Venn diagram (Figure 6) to emphasize the statements from similar or different $\mathrm{Q}$-sorts from the factors.

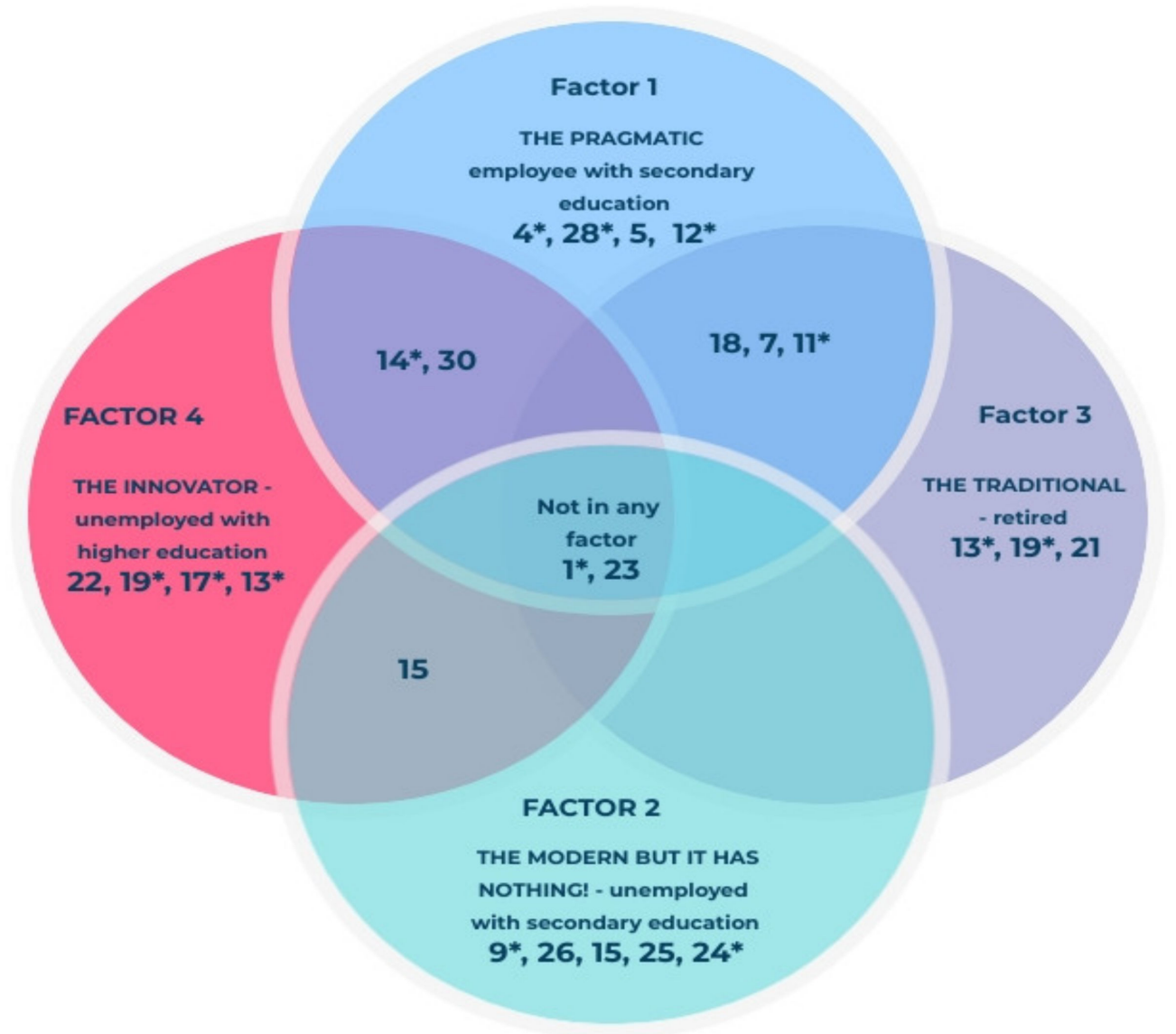

Figure 6. Venn diagram for the agree/disagree statements for each factor. (Note: ${ }^{*} p$-value $<0.01$ ).

The next important step in $\mathrm{Q}$ factor analysis is to calculate the z-scores, the factorial scores from gross scores, and weights for each factor. Figure 7 represents the z-scores.

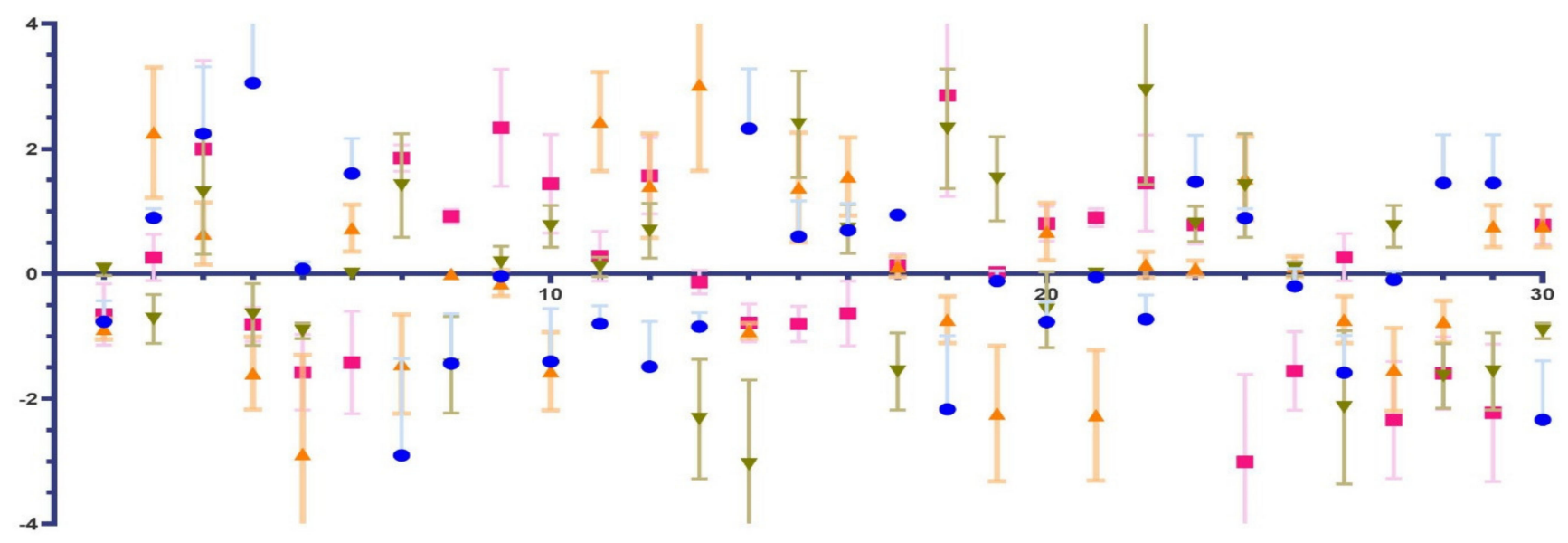

(Legend: $\bullet=$ Factor $1, \square=$ Factor $2, \Delta=$ Factor $3, \nabla=$ Factor 4 )

Figure 7. The Z-scores of each factor. 
Figure 2 presents the conversion in the structure of the Q-sort for each extracted factor. Due to statements that indicate the agreement or disagreement of the subjects with each factor, we named the factors as follows:

- Factor 1-The Pragmatic, represented by the employees with secondary education. Opposite statements for factor 1 are (4) The durable goods are a must in any household and (7) The new technologies are good for health.

- Factor 2-The Modern but it has nothing! represented by the unemployed with secondary education. Opposite statements for factor 2 are (18) A high price means a guaranteed quality and (9) I like to have the last generations of durable goods in comparison to (24) I change the durable goods when they break down only.

- Factor 3-The Traditional consumer, represented by the retired subjects of this study. Opposite statements for factor 3 are (13) Manufacturers of durable goods are constantly innovating to make household chores easier and increase comfort and (5) Romanian brands are competitive on the market.

- Factor 4-The Innovator, represented by the unemployed with higher education. Opposite statements for factor 4 are (22) Imported durable goods are better than Romanian one and (14) Durable goods made radiation harmful to health (microwave oven, tube monitors, mobile phones, TVs, etc.).

The $Q$ factor analysis being a statistical method has its own statistical indicators to characterize the factors and the reliability and goodness of fit from these results (Table 4).

Table 4. Statistical indicators for $Q$ factor analysis.

\begin{tabular}{ccccc}
\hline & \multicolumn{3}{c}{ Factors } \\
\cline { 2 - 5 } & $\mathbf{1}$ & $\mathbf{2}$ & $\mathbf{3}$ & $\mathbf{4}$ \\
\hline The number of defining & 7 subjects & 3 subjects & 2 subjects & 2 subjects \\
variables & 0.800 & 0.800 & 0.889 & 0.889 \\
Composite fidelity (>0.800) & 0.186 & 0.277 & 0.333 & 0.333 \\
Standard error of factor scores & & & & \\
Standard error of differences in & & & & \\
normalized factor scores: & 0.263 & 0.334 & 0.382 & 0.382 \\
1 & 0.334 & 0.392 & 0.434 & 0.434 \\
2 & 0.382 & 0.434 & 0.471 & 0.471 \\
3 & 0.382 & 0.434 & 0.471 & 0.471 \\
\hline
\end{tabular}

All four factors have a composite fidelity greater than 0.800 , which means that the more subjects who share the same opinions, the more confidence we have in the scores of the statements that form that factor. The standard errors have low values for all factors. The standard errors of differences in normalized factor scores show that, between factors 3 and 4 , statistically significant differences do not exist even if the subjects of each factor are different.

\subsection{Results for R Factor Analysis (Principal Component Analysis and Cluster Analysis)}

For R factor analysis (the PCA (Principal Component Analysis)), we used SPSS 23.0 (Licensed) and Graph Pad Prism 9 (Free Trial) for graphical representations of PCA and cluster analysis. Similar to $Q$ factor analysis, the Varimax rotation was used with Kaizer normalization. PCA is a very commonly used method; therefore, we present only the most important outputs of the methods. For variables of PCA, all 30 statements of the Q-sorts were used as variables. For cluster analysis, the resulting principal components of PCA were used to group all 30 subjects from the study. The number of clusters was chosen arbitrary as four as in $\mathrm{Q}$ methodology for uniform comparability. Table 5 presents the rotated component matrix from PCA. 
Table 5. Rotated component matrix (PCA).

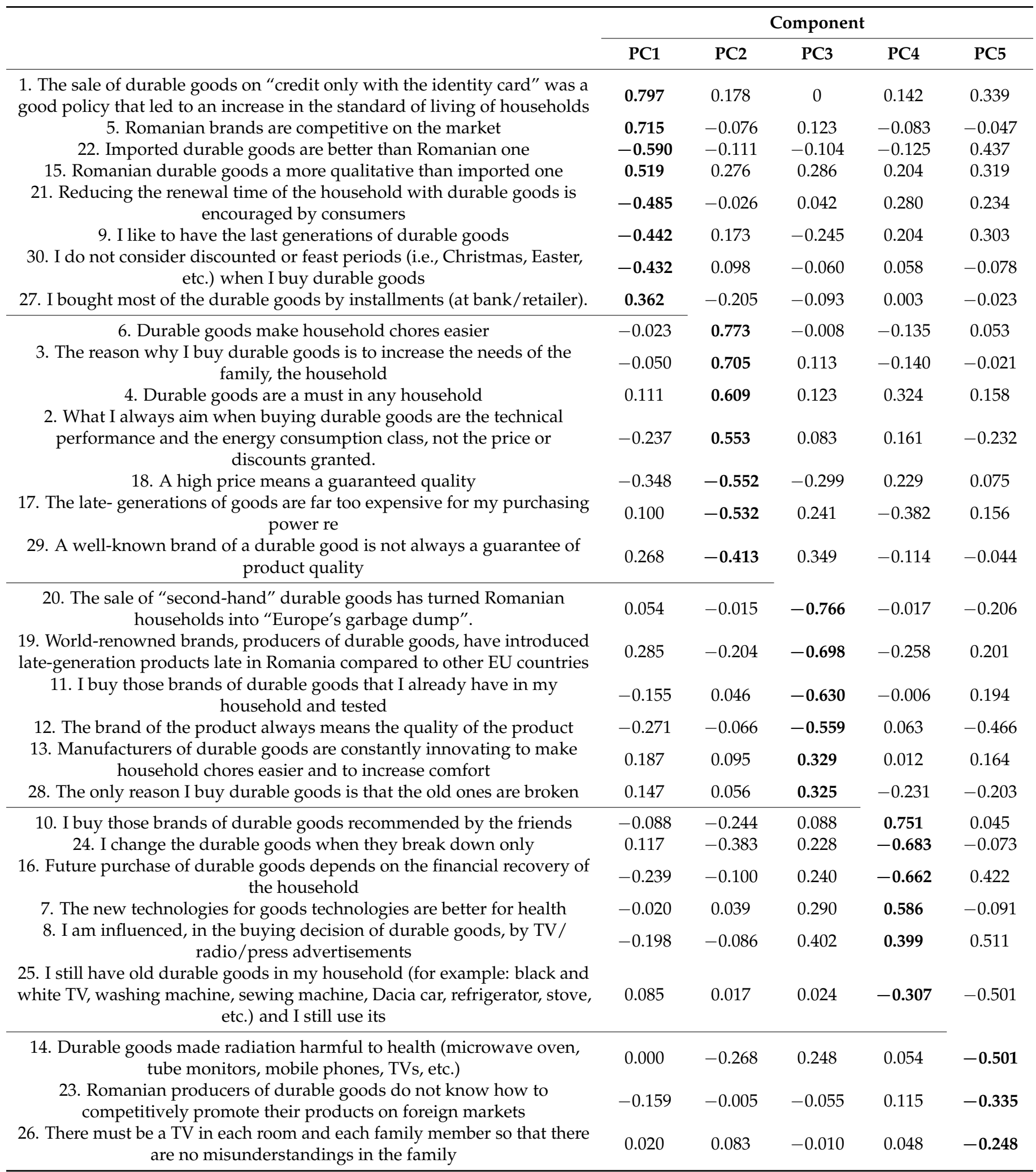

Extraction method: principal component analysis; rotation method: Varimax with Kaiser normalization; a. rotation converged in 7 iterations.

The five principal components (PC) from Table 5 explain only $47.334 \%$ of total variance. All five PCs contain both negative and positive values. In Figure 8 , the scree plot is presented. The decision for the number of PCs was an eigenvalue greater than 2 because 
the classical criterion $(>1)$ resulted in 12 PCs. Figure 9 presents the proportion of variance, individual and cumulative.

Eigenvalues

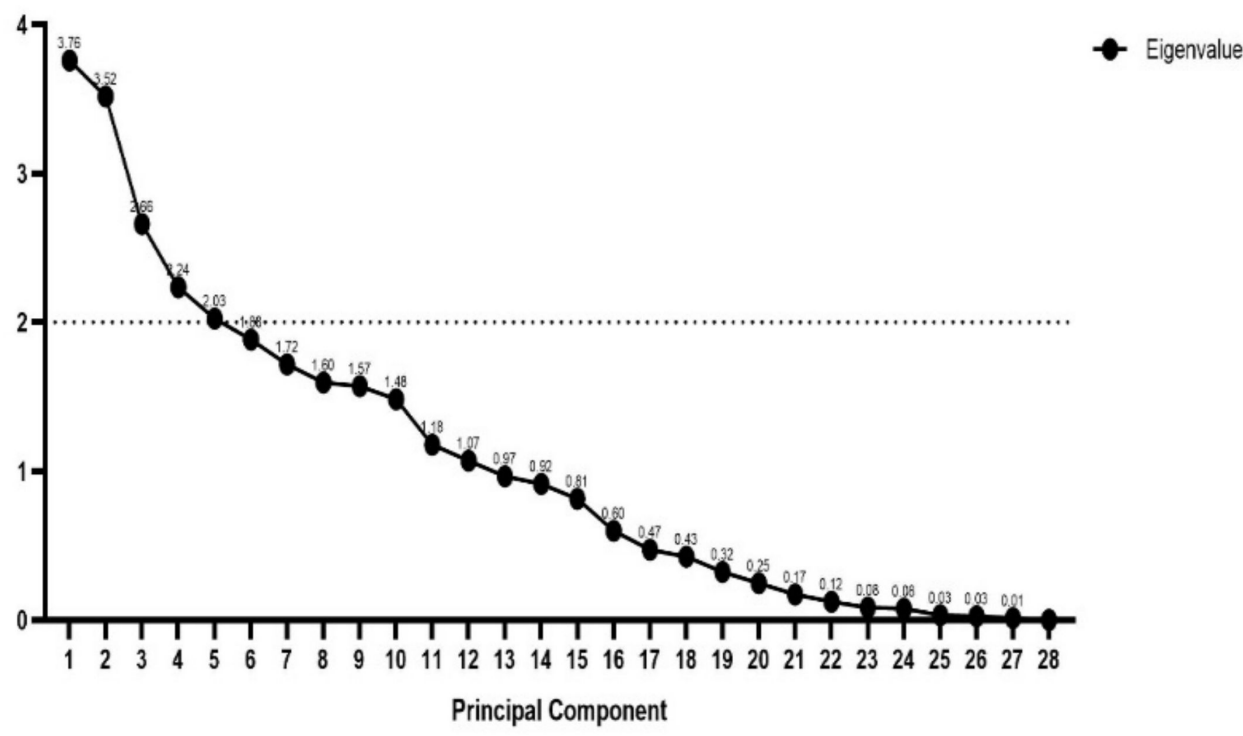

Figure 8. The scree plot for PCA.

\section{Proportion of variance}

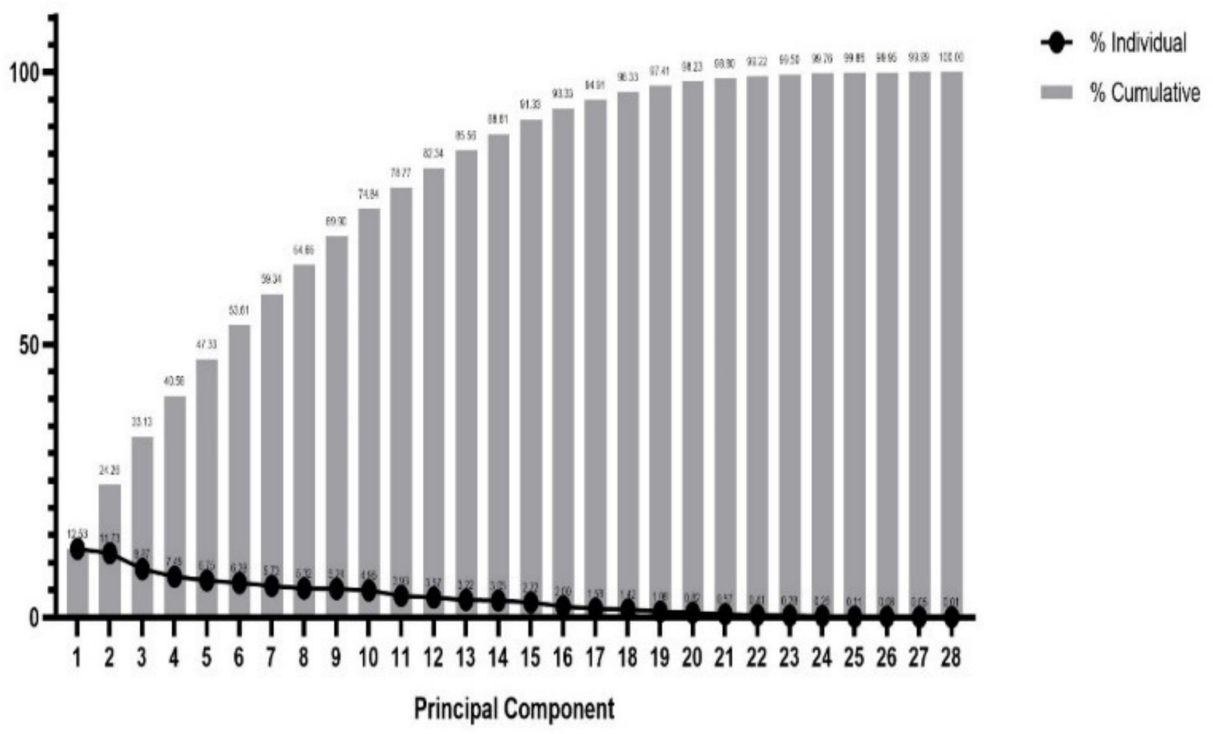

Figure 9. The proportion of variance.

Following the steps of the PCA method and after an analysis of the variables that form each PC, we can name the components as follows:

- $\quad$ PC1-traditional Romanian brands and behavior,

- PC2-real needs of households and power purchasing,

- PC3 - sceptic versus optimistic subjectiveness and opinions,

- PC4-oldest versus newest opinions on durable goods, and

- $\quad$ PC5-negative subjectiveness of durable goods buying behavior.

In Figure 10, the biplot (loadings and PC scores) are presented only for the first components PC1 and PC2. 


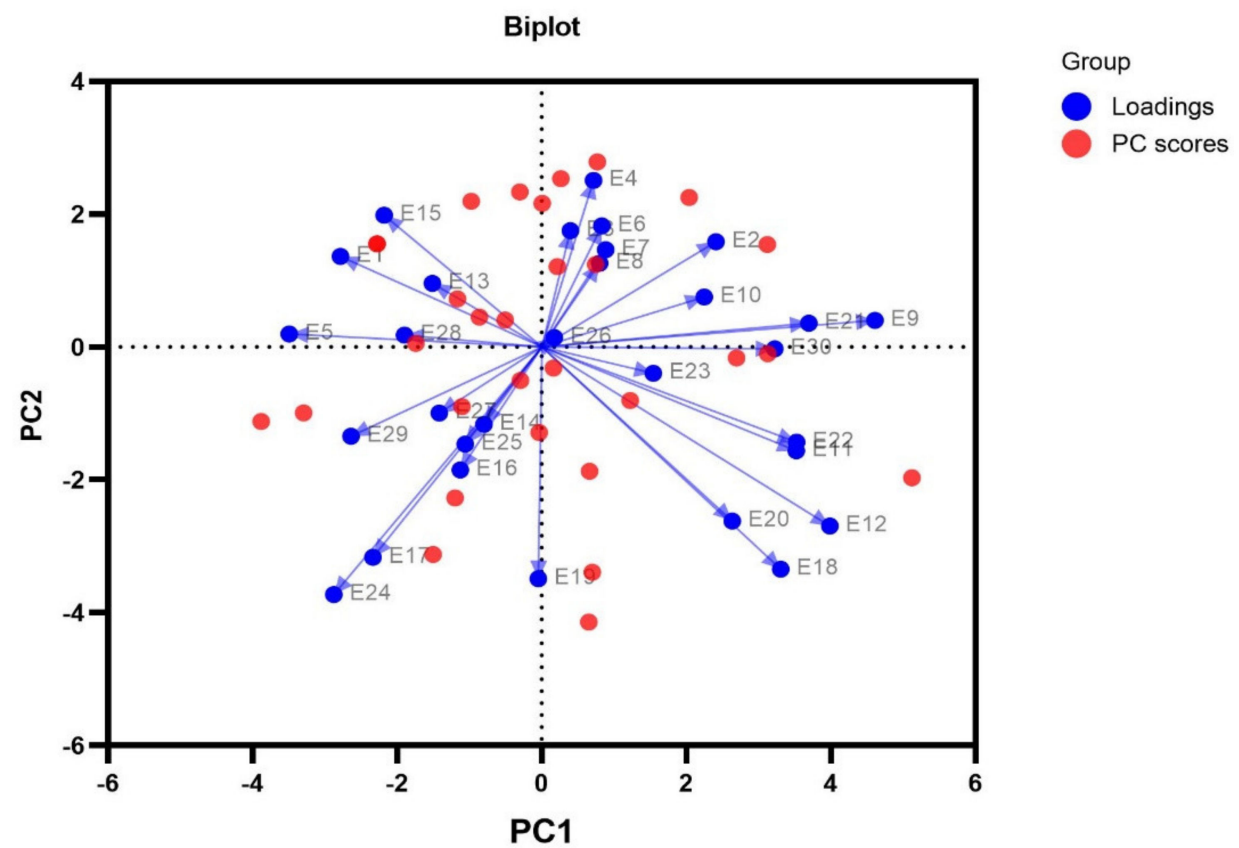

Figure 10. The biplot for PC1 and PC2.

To analyze how the 30 subjects are grouped on the five PCs, we applied the K-means cluster analysis. The ANOVA test indicates statistics significance for all clusters $(p<0.01$ for PC1 and PC2, $p=0.017$ for PC3, $p=0.005$ for PC4, and $p=0.049$ for PC5). The structure of the four final clusters are as follows:

- Cluster 1 has six members: one employee with higher education, one owner with secondary education, and four retired with secondary education.

- Cluster 2 has six members: one employee with higher education, one owner with higher education, one household member, and two employees with secondary education.

- Cluster 3 has 13 members: five employees with secondary education, one employee with higher education, one self-employed, one manager, one owner with secondary education, two retired with secondary education, and one unemployed with higher education.

- Cluster 4 has five members: one unemployed with higher education, one retired with gymnasium, one self-employed, one owner with secondary education, and one unqualified worker.

The heterogeneity of the clusters confirms the subjectiveness of perceptions and opinions. The clusters are heterogeneous if we consider the sociodemographic characteristics of the 30 subjects.

\section{Discussion}

The results of both factor analyses, $\mathrm{Q}$ and $\mathrm{R}$, comparatively show the advantages and disadvantages of the methods and the strengths and weaknesses of each method. Furthermore, for $\mathrm{R}$ factor analysis, we completed the PCA results with cluster analysis to obtain a closer and appropriate comparison of the PCA results with Q methodology.

Therefore, by applying the $Q$ methodology, we tried to identify some typologies of households in Tîrgu Mureş according to the sociodemographic characteristics of the head of the household. Our results partially confirmed that the international consumer behavior for durable goods is grouped into pragmatists; innovators/news searches/investors/modern; and actual [31], close to traditionalist. The rotation of the factors allowed us to obtain information regarding the similarity/differentiation between the 30 subjects from the study in terms of the four extracted factors, which subjects are similar, and who has conflicting opinions regarding the criteria for purchasing durable goods. The results of $Q$ 
methodology emphasizes the plurality [36] inside of P-sample that confirm the specific molecular hypothesis of the $\mathrm{Q}$ methodology and, in fact, the potential of durable goods market in Romania. The four extracted factors represent the four views of consumers. Through Q-sort, the method forced respondents to diversify their impact assessments [44] and thus provides valuable information for practical application in the decision-making process. In our study, an important aspect $[15,33]$ regarding the formulation and conception of statements included into Q-sorts for Q methodology is found. The methodology of applications for $Q$ factor analysis suggests that a researcher can obtain statements based on a literature study. Therefore, all 30 statements of our case study were selected, designed, and devised based on previous authors' research studies within the last 10 years [4-13] regarding the endowment of durable goods for Romanian households, the motivations and buying behavior for these goods, and their particularities for an ex-communist country.

In the $Q$ methodology, the factor matrix (Figure A2-from Appendix A) presents only the coordinates of the subjects on the four extracted factors but cannot be a major starting point in the internal and external interpretations of similarities and differences in opinion between research subjects. Figure 3 highlights only the groups of opinions of the subjects but do not refer to what each factor contains, which statements of the Q-sort-deck were grouped on each factor, and which statements were not represented at all in any factor.

Therefore, the separation, using as a differentiation criterion the standard error of differences (Table 2), in consensual statements and differentiating statements highlighted other aspects that help in the intrinsic interpretation of the results of the application of Q-factor analysis. Thus, we can conclude that differentiating statements refer to aspects such as the following:

- In the purchase of durable goods, the subjects consider aspects related to the energy consumption class and the technical performance of the good and not the price or discounts granted;

- the fact that the goods emit radiation harmful to health;

- The last generation of durable goods are expensive for the purchasing power of the subjects who were grouped on the four factors; and

- The reason for purchasing durable goods is that the old ones have been damaged.

On the last column of Table 2, for each subject (represented by the corresponding Q-sort), a weight that can be placed between 0 and 10 was obtained, with the maximum weight being assigned to the subject whose provisional weight was the highest, the subject that best characterizes that factor. Therefore, analyzing the results, it is found that there is strong grouping only among the second and fourth factors, as follows:

- For factor 1, the best characterization is given by subject 29 (employed with high school), and in descending order of importance, subject 26 and subject 24 , also employed with high school, because on the first factor, all employees with secondary education were grouped in the P-sample.

- For factor 2, the opposition of the opinions of the subjects that form this factor is very well highlighted and the grouping of subjects 7 and 8 (high school retirees) tend toward that of subject 18 (unskilled worker).

- For factor 3, the best characterization is given by subject 27 (employed with high school) and an average characterization is given by subject 2 (unemployed with high school).

- For factor 4, the defining characterization belongs to subject 19 (domestic), supplemented by that of subject 1 (unemployed with higher education).

These results show that the subjects who formed the four factors extracted in $Q$ methodology, being those who have a secondary education (unemployed, retirees, unqualified workers, homemakers, and employees with secondary education; the only subject with higher education was an unemployed person, who is thus a subject with low income) but have a significantly lower income than the other subjects, do not consider the aspects listed in the statements that differentiated the opinions of the subjects in this study. 
Based on the results from Table 3, we conclude the following:

- For factor 1, the highest weight is held by statement 4 . The subject that strongly defines this aspect is subject 1 - unemployed with higher education. The next highest weights are help by statements 14 and 3, defined by subjects 2 and 3-also unemployed but with high school education. Different statements and, therefore, opposite contributions in the formation of the first factor, have-in descending order of importance-defining statements from subjects $7,30,18,26,12$, and 8-all subjects with high school education. Therefore, this factor is formed by unemployed subjects and those employed with high school education. This cluster formed following the application of the Q methodology on the 30 statements regarding the opinions of the respondents from the marketing research undertaken in Tîrgu Mureş. Therefore, the subjects that form this factor think that "durable goods are a necessary good in any household", that the reason for purchasing these goods is to increase the needs of the household, and that these goods emit radiation harmful to health, statements with which they agree, opposed to those who refer to the fact that new technologies would be better for health; who are sensitive to promotional periods; who believe that high prices do not imply better quality and brand; who do not agree with the fact that, in every room of the house, there should be a TV; and who are not influenced by the promotion of these goods.

- For factor 2, statements $18,9,3$, and 7 have the highest positive weights, given by all three unemployed subjects and by subject 4 -retired with eight classes. Holding opposite opinions, subjects $24,27,29,28,5$, and 25 are defined as having secondary education in the P-sample; therefore, this second factor consists of the unemployed, employees with high school education, and those retired with high school education. Therefore, the subjects that form the second factor agree that the price is the guarantee of product quality, that they want to have state-of-the-art goods in the house, and that these are healthier than the old products. These opinions are "reinforced" by the opinions that the change in household goods is not always made only for the sake of replacing damaged goods, that the goods purchased for the most part are not purchased in installments, that world-famous brands guarantee product quality, and that Romanian brands do not present a strong competition on the world market.

- For factor 3, the subject characteristic of statement 13 is subject 1 -unemployed with higher education and who agrees with the fact that the sales policy adopted by Romanian companies to sell on "credit only with the bulletin" was one that contributed significantly to the increase in living standards in households from Tîrgu Mureş. This opinion is followed by statements 11,16 , and 24 for subjects 2,4 , and 5, i.e., a high school-educated unemployed person, a high school-educated retired person, and a high school-educated retired person; the opposing opinions were formed by the defining statements 5, 21, 19, 4, 10, and 27 for the subjects employed with high school education. Thus, the subjects of the third factor buy brands already tested and do not intend to purchase durable goods in the future unless there is a possibility of financial recovery of the household. However, there are opinions regarding the fact that the short renewal time of households is dictated not by consumers but by producers, that the frequency of the introduction of the latest generation and innovative products on the Romanian market has been synchronized with that on foreign markets and not with some temporary gap, and that the recommendation of friends in purchasing durable goods do not need to be considered.

- For factor 4, the major opinion is held by defining statements 22,18 , and 19 for the unemployed with higher education and high school education and for the high schooleducated retired persons whose opinions are in opposition to high school-educated employees who opt for statements $14,13,17,26,28$, and 29. Thus, the subjects of the fourth factor have positive opinions related to the following aspects: the imported durable goods are much better than Romanian ones, the price is the guarantee of quality, and there are some temporary gaps in the introduction of the latest innovations in Romania compared to other world markets. Opposite opinions are in regard to the 
fact that goods do not emit radiation harmful to health, that producers of goods do not strictly innovate litate "housework", and that state-of-the-art goods do not have "peppered" prices.

In Table 6, we structured the consensual and differentiating statements for each grouping factors, two by two. In bold are consensual or differentiating statements, and in italics are statements outside of these categories.

Table 6. Consensual and differentiating statements for each group of factors.

\begin{tabular}{ccc}
\hline Factor Grouping & Consensual Statements & Differentiating Statements \\
\hline Factor 1 and Factor 2 & $3,1,19,13,21,20,11,22,10,8,26,9,12,30,7,18$ & $4,24,29,14,28,6,27,5,17,15,25,16,2,23$ \\
Factor 1 and Factor 3 & $29,10,1,9,24,15,25,26,16,2,22,18,8,20,7,12,30,11,13$ & $4,14,5,28,21,19,3,27,23,6,17$ \\
Factor 1 and Factor 4 & $23,26,8,24,16,21,20,9,25,1,27,11,30,19,10,12,15,22,7,18$ & $14,4,28,29,17,2,6,5,13,3$ \\
Factor 2 and Factor 3 & $23,4,14,20,1,12,30,17,27,28,2,6,11,25,15,16,29,13,24$ & $18,21,7,9,10,19,26,3,8,5,22$ \\
Factor 2 and Factor 4 & $10,11,7,28,18,23,5,29,4,1,16,6,22,25,19,27,15,24$ & $26,8,14,30,13,9,17,20,2,3,21,12$ \\
Factor 3 and Factor 4 & $6,12,24,25,3,23,9,4,1,5,15,21,22,27,10,7,18,19$ & $13,2,11,29,17,30,14,8,26,28,16,20$ \\
\hline
\end{tabular}

Note: Consensual statements and differentiating statements are listed in descending order of the values of differences between factor scores.

The consensual statements resulting from the processing of Q-sorts refer to the following:

- The sale of durable goods on "credit only with identity card" was a good policy that increased in the standard of living of households.

- The last generations of durable goods are better for health.

- I buy those brands of durable goods for which I received the recommendation of my friends.

- I buy those brands of durable goods that I still have in the household and that are tested.

- the brand of the product means the quality of the product.

- A high price means a guaranteed quality.

- The sale of "second-hand" durable goods has transformed Romanian households into "Europe's garbage dump".

- Imported durable goods are better than Romanian brands.

- I do not consider the periods with discounts or holidays when I buy durable goods.

According to $\mathrm{Q}$ methodology' results, the four typologies of consumers are sensitive to aspects related to the reliability and maintenance of the product, aspects revealed by the low purchasing power (which pay attention to the energy consumption class, which brings savings to the household budget). If we consider these consensual statements, the subjects who formed the four factors hold similar opinions regarding bank lending policies, fear of trying a brand other than the one already owned, the brand and price representing a guarantee of product quality, preferences for imported goods to those of local production, and making purchases regardless of the time of year.

Our results show that $Q$ methodology is a robust tool [45] and congruent method [46] for informing on the decision-making process and quantifying Romanian household's subjectiveness about durable goods market.

\section{Conclusions}

With the present comparative analysis, we highlighted (and, in conclusion, we recommend) that, for measuring subjectivity and latent variables in consumer behavior, there is a rigorous method: $Q$ factor analysis based on grouping the subjects according to their perceptions, subjectiveness, and opinions. Nowadays, in marketing research, consumer behaviors, and behavior economy, market segments are becoming increasingly narrow due - on the one hand - to the numerous products and services and - on the other handto the various strategies of producers to attract a typical consumer. The research results provide also useful suggestions for selecting and approaching target consumer segments in the Romanian durable goods industry, both for Romanian and global brands. Regarding 
policymakers for the durable goods market, the present results help to understand Romanian consumers and their subjectiveness: endowment with durable goods in Romania is-from the subjective perspective-equal to social status. All four factors from Q methodology confirm the four types of Romanian households with different buying behavior and motivations for durable goods purchases. They are sensitive to the price but open to the last technologies, and they are traditionalist and conservatives. All of this information is needed for policy makers involved in the Romanian durable goods market.

As there are many adherents of the "classical" methods of factor analysis who dispute the quality of Q-factor analysis, we recommend this method for the benefits, highlighting that the $\mathrm{Q}$ methodology and related programs provide additional indicators, necessary for better internal interpretation and more detailed than an R-factor analysis performed, for example, with SPSS. The major advantage is that it gives the possibility to highlight and, especially, to understand both the similarities between the subjects-the variables-and especially the differences between them, helping identify those opinions that differentiate the subjects. Moreover, the $\mathrm{Q}$ method identified subjects who actively and definitively participate in the formation of the extracted factors and, therefore, of the "formative" opinions of factors. In Table 7, we present the advantages and limits of using $Q$ factor analysis.

Table 7. Advantages and disadvantages of using of $Q$ factor analysis.

\begin{tabular}{|c|c|}
\hline Advantages & Limits \\
\hline $\begin{array}{l}\text { The process is short. } \\
\text { It is a systematic approach in which preferences are categorized. } \\
\text { Implementation is easy.It provides a means of studying small samples } \\
\text { of population [47]. } \\
\text { It can be used together with explanatory research [33]. } \\
\text { It captures operant subjectiveness by using auto-references [48]. } \\
\text { The participant is not selected randomly.Standard error of factor } \\
\text { scores.It can be managed via the Internet (http:// qmethod.org) [37]. } \\
\text { It protects auto-references issued by individuals by researcher's } \\
\text { influence [49,50]. } \\
\text { A Likert scale is not used individually for every item but starts from the } \\
\text { relation between items [51]. }\end{array}$ & $\begin{array}{l}\text { The number of choices required from respondents } \\
\text { within a relatively short time is high. } \\
\text { The number of cards/items / statements introduced in } \\
\text { the process is concerning. The perspectives of individuals } \\
\text { is temporary and can change with time or under } \\
\text { different circumstances [33]. } \\
\text { The researcher's presence adds pressure [48]. } \\
\text { Statistical inference of the results is impossible [52]. }\end{array}$ \\
\hline
\end{tabular}

Source: $[28,53,54]$.

Compared with the $\mathrm{R}$ method, the $\mathrm{Q}$ methodology is a relatively simple type of empirical or quantitative study [15]. The variable of $R$ consists of measurable items or stimuli, whereas that of $Q$ methodology is a person [15], which is a critical aspect in consumer behavior research. $Q$ factor analysis help to identify levels of consensus and divergence among subjects [55], and this method search for factors or groups within the data of participants who have similar opinions [56].

Another important advantage for using the $Q$ methodology for subjectiveness measurement is that there is a constructive-conclusive- "connection" between subjects as variables of factor analysis and statements as variables that help form variables-subjects that are factored. Therefore, this study shows that, for Romanian consumers from Tîrgu Mureş with a low level of income, although they want to own and purchase durable goods of the latest generation, they cannot afford them or they "switch" to such purchases only when "the old ones have broken down."

The $Q$ methodology is an excellent combination of both qualitative and quantitative analysis with free and easy-to-use software. The $Q$ factor analysis highlights aspects related to perceptions, subjectivism, similar or different opinions, and intrinsic characteristics of the subjects; for example, those aspects are highlighted and interpreted in depth when combining qualitative research methods and those of quantitative research, such as in the $\mathrm{Q}$ methodology. 
Author Contributions: Conceptualization, M.R.G.; methodology, M.R.G.; software, M.R.G.; validation, M.R.G. and N.C.; formal analysis, M.R.G.; investigation, M.R.G. and N.C.; resources, N.C.; writing—original draft preparation, M.R.G.; writing—review and editing, M.R.G. and N.C.; funding acquisition, N.C. All authors have read and agreed to the published version of the manuscript.

Funding: This research received no external funding.

Institutional Review Board Statement: Not applicable.

Informed Consent Statement: Informed consent was obtained from all subjects involved in the study.

Data Availability Statement: Not applicable.

Acknowledgments: This research was supported by “Dunărea de Jos" University of Galați, Galați, Romania.

Conflicts of Interest: The authors declare no conflict of interest.

\section{Appendix A}

\begin{tabular}{|c|c|c|c|c|c|c|c|c|c|c|c|c|c|c|c|c|c|c|c|c|c|c|c|c|c|c|c|c|c|c|}
\hline SOR & 1 & 2 & 3 & 4 & 3 & & 7 & 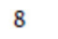 & 9 & 0 & 1 & 2 & 3 & 4 & 5 & 16 & 7 & 18 & 9 & 20 & 1 & 2 & 3 & 24 & 5 & 6 & 7 & 28 & 9 & 0 \\
\hline $\begin{array}{l}\text { patronsu } \\
\text { patrlic1 } \\
\text { patrlic2 } \\
\text { patrlic3 } \\
\text { mnecalif } \\
\text { casnica } \\
\text { angsup1 } \\
\text { angsup2 } \\
\text { angsup3 } \\
\text { angsup4 } \\
\text { anglic1 } \\
\text { anglic2 } \\
\text { anglic3 } \\
\text { anglic4 } \\
\text { anglic5 } \\
\text { anglic6 } \\
\text { anglic7 }\end{array}$ & $\begin{array}{r}100 \\
7 \\
25 \\
25 \\
-21 \\
3 \\
24 \\
-10 \\
5 \\
13 \\
-17 \\
-1 \\
35 \\
40 \\
-4 \\
-8 \\
-17 \\
14 \\
-32 \\
17 \\
15 \\
5 \\
19 \\
5 \\
31 \\
25 \\
7 \\
15 \\
-3 \\
3\end{array}$ & $\begin{array}{r}7 \\
100 \\
28 \\
5 \\
-23 \\
12 \\
9 \\
4 \\
-1 \\
29 \\
13 \\
4 \\
0 \\
34 \\
12 \\
10 \\
-16 \\
-7 \\
8 \\
18 \\
32 \\
23 \\
1 \\
12 \\
6 \\
28 \\
28 \\
18 \\
24 \\
42\end{array}$ & $\begin{array}{r}25 \\
28 \\
100 \\
5 \\
-3 \\
3 \\
41 \\
40 \\
38 \\
21 \\
17 \\
2 \\
53 \\
14 \\
10 \\
25 \\
-19 \\
37 \\
13 \\
33 \\
45 \\
30 \\
35 \\
27 \\
45 \\
100 \\
1 \\
15 \\
47 \\
43\end{array}$ & $\begin{array}{r}25 \\
5 \\
5 \\
100 \\
-5 \\
-25 \\
5 \\
-17 \\
7 \\
-16 \\
-24 \\
-5 \\
11 \\
-8 \\
40 \\
-5 \\
6 \\
29 \\
-15 \\
9 \\
6 \\
-7 \\
22 \\
37 \\
9 \\
5 \\
-14 \\
-6 \\
5 \\
-15\end{array}$ & $\begin{array}{r}-21 \\
-23 \\
-3 \\
-5 \\
100 \\
10 \\
12 \\
28 \\
19 \\
30 \\
9 \\
-8 \\
0 \\
-14 \\
-6 \\
10 \\
-18 \\
16 \\
15 \\
21 \\
-2 \\
-6 \\
33 \\
15 \\
-15 \\
-3 \\
-9 \\
15 \\
4 \\
-14\end{array}$ & $\begin{array}{r}3 \\
12 \\
3 \\
-25 \\
10 \\
100 \\
6 \\
19 \\
22 \\
2 \\
39 \\
9 \\
-1 \\
-2 \\
4 \\
4 \\
25 \\
9 \\
-18 \\
-1 \\
-22 \\
16 \\
-7 \\
4 \\
24 \\
3 \\
1 \\
1 \\
17 \\
-7\end{array}$ & $\begin{array}{r}24 \\
9 \\
41 \\
5 \\
12 \\
6 \\
100 \\
62 \\
12 \\
-6 \\
-11 \\
-17\end{array}$ & $\begin{array}{r}-10 \\
4 \\
40 \\
-17 \\
28 \\
19 \\
62 \\
100 \\
-6 \\
7 \\
-1 \\
-17 \\
23 \\
6 \\
38 \\
34 \\
-42 \\
60 \\
19 \\
44 \\
11 \\
-6 \\
36 \\
-5 \\
3 \\
40 \\
8 \\
-7 \\
46 \\
24\end{array}$ & $\begin{array}{r}5 \\
-1 \\
38 \\
7 \\
19 \\
22 \\
12 \\
-6 \\
100 \\
10 \\
34 \\
22 \\
26 \\
5 \\
2 \\
12 \\
3 \\
6 \\
13 \\
26 \\
49 \\
14 \\
42 \\
30 \\
29 \\
38 \\
-1 \\
12 \\
25 \\
44\end{array}$ & $\begin{array}{r}13 \\
29 \\
21 \\
-16 \\
30 \\
2 \\
-6 \\
7 \\
10 \\
100 \\
33 \\
18 \\
15 \\
53 \\
-12 \\
31 \\
-9 \\
14 \\
13 \\
26 \\
30 \\
16 \\
26 \\
38 \\
24 \\
21 \\
7 \\
41 \\
46 \\
13\end{array}$ & $\begin{array}{r}-17 \\
13 \\
17 \\
-24 \\
9 \\
39 \\
-11 \\
-1 \\
34 \\
33 \\
100 \\
26 \\
20 \\
24 \\
14 \\
12 \\
45 \\
4 \\
8 \\
15 \\
22 \\
43 \\
17 \\
47 \\
18 \\
17 \\
-15 \\
42 \\
30 \\
5\end{array}$ & $\begin{array}{r}-1 \\
4 \\
2 \\
-5 \\
-8 \\
9 \\
-17 \\
-17 \\
22 \\
18 \\
26 \\
100 \\
-18 \\
-11 \\
-6 \\
15 \\
-2 \\
10 \\
-1 \\
24 \\
4 \\
28 \\
10 \\
-1 \\
13 \\
2 \\
-11 \\
28 \\
25 \\
2\end{array}$ & $\begin{array}{r}35 \\
0 \\
53 \\
11 \\
0 \\
-1 \\
12 \\
23 \\
26 \\
15 \\
20 \\
-18 \\
100 \\
23 \\
35 \\
22 \\
-10 \\
27 \\
0 \\
36 \\
25 \\
22 \\
21 \\
24 \\
12 \\
53 \\
0 \\
2 \\
13 \\
13\end{array}$ & $\begin{array}{r}40 \\
34 \\
14 \\
-8 \\
-14 \\
-2 \\
15 \\
6 \\
5 \\
53 \\
24 \\
-11 \\
23 \\
100 \\
1 \\
10 \\
0 \\
10 \\
9 \\
37 \\
42 \\
17 \\
28 \\
23 \\
40 \\
14 \\
25 \\
43 \\
32 \\
36\end{array}$ & $\begin{array}{r}-4 \\
12 \\
10 \\
40 \\
-6 \\
4 \\
25 \\
38 \\
2 \\
-12 \\
14 \\
-6 \\
35 \\
1 \\
100 \\
25 \\
17 \\
64 \\
12 \\
35 \\
0 \\
0 \\
15 \\
20 \\
-9 \\
10 \\
4 \\
-15 \\
30 \\
0\end{array}$ & $\begin{array}{r}-8 \\
10 \\
25 \\
-5 \\
10 \\
4 \\
15 \\
34 \\
12 \\
31 \\
12 \\
15 \\
22 \\
10 \\
25 \\
100 \\
-15 \\
28 \\
29 \\
7 \\
-4 \\
43 \\
40 \\
4 \\
8 \\
25 \\
1 \\
29 \\
45 \\
33\end{array}$ & $\begin{array}{r}-17 \\
-16 \\
-19 \\
6 \\
-18 \\
25 \\
-43 \\
-42 \\
3 \\
-9 \\
45 \\
-2 \\
-10 \\
0 \\
17 \\
-15 \\
100 \\
-5 \\
-15 \\
-16 \\
-16 \\
33 \\
-18 \\
21 \\
16 \\
-19 \\
-5 \\
10 \\
-2 \\
-25\end{array}$ & $\begin{array}{r}14 \\
-7 \\
37 \\
29 \\
16 \\
9 \\
35 \\
60 \\
6 \\
14 \\
4 \\
10 \\
27 \\
10 \\
64 \\
28 \\
-5 \\
100 \\
14 \\
52 \\
7 \\
8 \\
44 \\
30 \\
20 \\
37 \\
5 \\
-8 \\
55 \\
5\end{array}$ & $\begin{array}{r}12 \\
29 \\
-15 \\
14 \\
100 \\
-12 \\
8 \\
0 \\
14 \\
31 \\
-10 \\
13 \\
-1 \\
5 \\
12 \\
31\end{array}$ & $\begin{array}{r}35 \\
7 \\
-16 \\
52 \\
-12 \\
100 \\
59 \\
22 \\
46 \\
1 \\
22 \\
33 \\
13 \\
5 \\
40 \\
25\end{array}$ & $\begin{array}{r}0 \\
-4 \\
-16 \\
7 \\
8 \\
59 \\
100 \\
24 \\
45 \\
15 \\
28 \\
45 \\
16 \\
15 \\
18 \\
41\end{array}$ & $\begin{array}{r}5 \\
23 \\
30 \\
-7 \\
-6 \\
16 \\
-30 \\
-6 \\
14 \\
16 \\
43 \\
28 \\
22 \\
17 \\
0 \\
43 \\
33 \\
8 \\
0 \\
22 \\
24 \\
100 \\
28 \\
9 \\
25 \\
30 \\
6 \\
54 \\
11 \\
8\end{array}$ & $\begin{array}{r}21 \\
28 \\
15 \\
40 \\
-18 \\
44 \\
14 \\
46 \\
45 \\
28 \\
100 \\
35 \\
11 \\
35 \\
4 \\
25 \\
51 \\
35\end{array}$ & $\begin{array}{r}5 \\
12 \\
27 \\
37 \\
15 \\
4 \\
0 \\
-5 \\
30 \\
38 \\
47 \\
-1 \\
24 \\
23 \\
20 \\
4 \\
21 \\
30 \\
31 \\
1 \\
15 \\
9 \\
35 \\
100 \\
9 \\
27 \\
-11 \\
16 \\
32 \\
3\end{array}$ & $\begin{array}{r}31 \\
6 \\
45 \\
9 \\
-15 \\
24 \\
-4 \\
3 \\
29 \\
24 \\
18 \\
13 \\
12 \\
40 \\
-9 \\
8 \\
16 \\
20 \\
-10 \\
22 \\
28 \\
25 \\
11 \\
9 \\
100 \\
45 \\
-20 \\
17 \\
41 \\
24\end{array}$ & $\begin{array}{r}30 \\
21 \\
17 \\
2 \\
53 \\
14 \\
10 \\
25 \\
-19 \\
37 \\
13 \\
33 \\
45 \\
30\end{array}$ & $\begin{array}{r}7 \\
28 \\
1 \\
-14 \\
-9 \\
1 \\
3 \\
8 \\
-1 \\
7 \\
-15 \\
-11 \\
0 \\
25 \\
4 \\
1 \\
-5 \\
5 \\
-1 \\
13 \\
16 \\
6 \\
4 \\
-11 \\
-20 \\
1 \\
100 \\
25 \\
11 \\
23\end{array}$ & $\begin{array}{r}15 \\
18 \\
15 \\
-6 \\
15 \\
1 \\
-1 \\
-7 \\
12 \\
41 \\
42 \\
28 \\
2 \\
43 \\
-15 \\
29 \\
10 \\
-8 \\
5 \\
5 \\
15 \\
54 \\
25 \\
16 \\
17 \\
15 \\
25 \\
100 \\
23 \\
9\end{array}$ & $\begin{array}{r}-3 \\
24 \\
47 \\
5 \\
4 \\
17 \\
36 \\
46\end{array}$ & $\begin{array}{r}3 \\
42 \\
43 \\
-15 \\
-14 \\
-7\end{array}$ \\
\hline
\end{tabular}

Figure A1. The correlation matrix based on completed Q-sorts using the P-sample. 


\begin{tabular}{|c|c|c|c|c|c|}
\hline \multicolumn{6}{|c|}{ Loadings } \\
\hline & SORT & 1 & 2 & 3 & 4 \\
\hline 1 & somersup & 0.0327 & -0.0939 & -0.7108 & -0.0823 \\
\hline 2 & somerli1 & 0.0270 & 0.0250 & $0.0336 x$ & -0.6929 \\
\hline 3 & somerli2 & 0.2610 & -0.0723 & 0.0016 & -0.1152 \\
\hline 4 & pens $8 \mathrm{c} 7 \mathrm{~s}$ & 0.3030 & 0.2192 & -0.2105 & 0.1271 \\
\hline 5 & penslic1 & 0.1575 & -0.2356 & 0.2612 & 0.6108 \\
\hline 6 & penslic2 & 0.1564 & 0.3074 & -0.1462 & 0.1229 \\
\hline 7 & penslic3 & 0.4663 & $-0.4678 x$ & 0.0589 & -0.0100 \\
\hline 8 & penslic4 & 0.7067 & $-0.4298 x$ & 0.1452 & -0.0009 \\
\hline 9 & penslic5 & -0.0559 & 0.0634 & 0.1572 & 0.2533 \\
\hline 10 & penslic6 & 0.0580 & 0.0320 & 0.0388 & -0.0783 \\
\hline 11 & 1ibprof1 & 0.0606 & 0.6013 & 0.1840 & 0.0802 \\
\hline 12 & manager & -0.0033 & 0.0311 & -0.0091 & 0.1094 \\
\hline 13 & 1ibprof2 & 0.3125 & 0.1102 & -0.1780 & -0.0026 \\
\hline 14 & patr & 0.0636 & 34 & -0.2 & -0.4566 \\
\hline 15 & patrlic1 & 0.8120 & 0.2657 & 0.0557 & -0.1305 \\
\hline 16 & patrlic2 & 0.4144 & -0.0724 & 0.3639 & -0.1865 \\
\hline 17 & patrlic3 & -0.0439 & 0.8327 & -0.0681 & 0.0190 \\
\hline 18 & mnecalif & 0.8789 & $0.0052 x$ & -0.0556 & 0.1034 \\
\hline 19 & casnica & 0.0741 & -0.0377 & 0.7733 & $-0.1410 x$ \\
\hline 20 & angsup1 & 0.4999 & -0.2438 & -0.3028 & 0.0048 \\
\hline 21 & angsup2 & -0.0435 & -0.1826 & -0.0855 & -0.1617 \\
\hline 22 & angsup 3 & 0.0534 & 0.3468 & -0.0474 & -0.2020 \\
\hline 23 & angsup4 & 0.4279 & -0.2158 & 0.1058 & 0.1617 \\
\hline 24 & angli & $0.1969 x$ & 0.5293 & 0.2736 & 0.1431 \\
\hline 25 & anglic2 & $0.0094 x$ & 0.2023 & -0.3636 & -0.0166 \\
\hline 26 & anglic3 & $0.2610 x$ & -0.0723 & 0.0016 & -0.1152 \\
\hline 27 & ang1ic4 & $0.0824 \mathrm{X}$ & -0.1829 & $-0.0754 x$ & -0.5700 \\
\hline 28 & ang 1 ic5 & $-0.0670 x$ & 0.1359 & -0.0144 & -0.2015 \\
\hline 29 & ang $1 i c 6$ & $0.5737 x$ & 0.0141 & 0.1325 & -0.1664 \\
\hline 30 & anglic7 & $0.0320 x$ & -0.2844 & 0.2848 & -0.4758 \\
\hline$\% \in$ & expl.Var. & 12 & 8 & 7 & \\
\hline
\end{tabular}

Figure A2. The factor matrix ( $\mathrm{X}$ indicates the defining $\mathrm{Q}$-sort).

\section{References}

1. Song, S.; Ko, E. Perceptions, attitudes, and behaviors toward sustainable fashion: Application of Q and Q-R methodologies. Int. J. Consum. Stud. 2017, 41, 264-273. [CrossRef]

2. Van Eijk, C.; Steen, T.; Verschuere, B. Co-producing safety in the local community: A Q-methodology study on the incentives of Belgian and Dutch members of neighborhood watch schemes. Local Gov. Stud. 2017, 43, 323-343. [CrossRef]

3. Zabala, A. Qmethod: A package to explore human perspectives using Q methodology. R J. 2014, 6, 163-173. [CrossRef]

4. Gabor, M.R.; Ştefănescu, D.; Conţiu, L.C. Marketing research regarding the technological changes and the endowment with durable goods of Romanian households. In Proceedings of the 6th International Conference "Management of Technological Changes", Alexandroupolis, Greece, 3-5 September 2009; Volume I, pp. 229-232.

5. Gabor, M.R.; Ştefănescu, D.; Conţiu, L.C. Statistical methods-components of differentiation strategies of durable goods market in Romania. In Proceedings of the 18th International Economic Conference-IECS 2011, Crises after crises. Inquiries from a national, European and global perspective, Sibiu, Romania, 19-20 May 2011.

6. Gabor, M.R.; Isaic-Maniu, A. Analysis of the discriminating-applications identifying the preference of endowment with goods. Revista Română de Statistică 2011, 10, 51-77.

7. Gabor, M.R.; Isaic-Maniu, A. Identificarea principalelor surse de informaţii în achiziţionarea bunurilor de folosinţă îndelungată folosind analiza factorială a corespondenţelor (Identification of the main sources of information in the acquisition of durable goods using factorial correspondence analysis). Studii si Cercetări de Calcul Economic și Cibernetică Economică 2011, 1-2, 55-67. 
8. Gabor, M.R. Positioning of brand concerning durable goods and other variables used in the Romanian consumer's acquisition process. Actual Probl. Econ. 2012, 8, 357-372.

9. Gabor, M.R. Are the differences referring to the living standard in Romania according to the occupational status? Empirical research referring to the endowment with durable goods in Romanian households. Ann. Constantin Brancusi Univ. Targu Jiu Econ. Ser. 2012, 3, 117-124.

10. Gabor, M.R. Endowment of households with durable goods-Indicator of welfare and life quality. Empirical study regarding post-communist behavior of Romanian consumers. Inz. Ekon. Eng. Econ. 2013, 24, 244-253. [CrossRef]

11. Gabor, M.R. Retailer-consumer relationships for durable goods market in Romania. A multimethod analysis. Int. J. Econ. Behav. 2014, 4, 67-82.

12. Gabor, M.R.; Conţiu, L.C. Endowment with durable goods-Welfare indicator of Romanian family. In Child and Family Welfare; ASA, Collection; Iovu, M.B., Rață, G., Runcan, P.L., Eds.; Cambridge Scholars Publishing: Newcastle, UK, 2014 ; pp. 163-173.

13. Gabor, M.R.; Oltean, F.D. Is the old communist brand preferred by the young consumers? A country of origin study case with multimethod analysis. Risk Contemp. Econ. 2018, 355-366. [CrossRef]

14. Phelan, C. Identifying entrepreneurial competencies using Q methodology: An innovative research approach. In Book Series, Proceedings of the European Conference on Research Methodology for Business and Management; Academic Conferences and Publishing International Limited: Valletta, Malta, 2015; pp. 322-330.

15. Kim, K.Y.; Lee, B.G. Marketing insights for mobile advertising and consumer segmentation in the cloud era: A Q-R hybrid methodology and practices. Technol. Forecast. Soc. Chang. 2015, 91, 78-92. [CrossRef]

16. Bredin, Y.K.; Lindhjem, H.; van Dijk, J.; Linnell, J.D. Mapping value plurality towards ecosystem services in the case of Norwegian wildlife management: A Q analysis. Ecol. Econ. 2015, 118, 198-206. [CrossRef]

17. Jensen, A.K. A Structured approach to attribute selection in economic valuation studies: Using Q-methodology. Ecol. Econ. 2019, 166, 106400. [CrossRef]

18. Chung, A.; Kinsey, D.F. An examination of consumers' subjective views that affect the favorability of organizational logos: An exploratory study using Q methodology. Corp. Reput. Rev. 2019, 22, 89-100. [CrossRef]

19. Sneegas, G.; Beckner, S.; Brannstrom, C.; Jepson, W.; Lee, K.; Seghezzo, L. Using Q-methodology in environmental sustainability research: A bibliometric analysis and systematic review. Ecol. Econ. 2021, 180, 106864. [CrossRef]

20. Berghout, M.; Van Exel, J.; Leensvaart, L.; Cramm, J.M. Healthcare professionals' views on patient-centered care in hospitals. BMC Health Serv. Res. 2015, 15, 1-13. [CrossRef] [PubMed]

21. Grimshaw, P.; McGowan, L.; McNichol, E. An extra care community's perceived priority for 'whole system' relationships: A Q-methodological study. Health Soc. Care Community 2017, 25, 1169-1180. [CrossRef] [PubMed]

22. Thammasitboon, S.; Mariscalco, M.M.; Yudkowsky, R.; Hetland, M.D.; Noronha, P.A.; Mrtek, R.G. Exploring individual opinions of potential evaluators in a 360-degree assessment: Four distinct viewpoints of a competent resident. Teach. Learn. Med. 2008, 20, 314-322. [CrossRef] [PubMed]

23. Palese, A.; Bottega, M.; Cescutti, A.; Caruzzo, D.; Danielis, M.; Fabris, S.; Mattiussi, E.; Grassetti, L. Depicting clinical nurses' priority perspectives leading to unfinished nursing care: A pilot Q methodology study. J. Nurs. Manag. 2020, 28, 2146-2156. [CrossRef]

24. Banna, S.; Hasan, H.; Dawson, P. Understanding the diversity of user requirements for interactive online health services. Int. J. Healthc. Technol. Manag. 2016, 15, 253-271. [CrossRef]

25. Winkler, K.J.; Nicholas, K.A. More than wine: Cultural ecosystem services in vineyard landscapes in England and California. Ecol. Econ. 2016, 124, 86-98. [CrossRef]

26. Lehong, S.M.; Dube, E.; Angelopoulos, G. An investigation into the perceptions of business stakeholders on the benefits of enterprise architecture: The case of Telkom SA. S. Afr. J. Bus. Manag. 2013, 44, 45-56. [CrossRef]

27. Brown, S.R. Political Subjectivity: Applications of Q Methodology in Political Science; Yale University Press: New Haven, CT, USA, 1980.

28. Gabor, M.R. Analiza și Inferența Datelor de Marketing; Analysis and Inference of Marketing Data; C. H. Beck: Bucharest, Romania, 2016.

29. Silvius, G.; Schipper, R. Exploring variety in factors that stimulate project managers to address sustainability issues. Int. J. Proj. Manag. 2020, 38, 353-367. [CrossRef]

30. Krabbenborg, L.; Molin, E.; Annema, J.A.; van Wee, B. Public frames in the road pricing debate: A Q-methodology study. Transp. Policy 2020, 93, 46-53. [CrossRef]

31. Liu, C.C.; Chen, J.C.H.; Poon, C.C. Perception types of home buyers by q methodology: A comparative study of Hong Kong, Taiwan, and the USA. Singap. Econ. Rev. 2019, 64, 235-257. [CrossRef]

32. Pintilescu, C. Analiza datelor; Data analysis; Junimea: Bucharest, Romania, 2003.

33. Iliescu, D. Metodologia Q; Q Methodology; Comunicare: Bucharest, Romania, 2005.

34. McKeown, B.; Thomas, D. Q Methodology; (Series University Paper); SAGE Publications: London, UK, 1988. [CrossRef]

35. Brown, S.R. Q methodology tutorial. Operant Subj. 1993, 16, 91-138.

36. Hermelingmeier, V.; Nicholas, K.A. Identifying five different perspectives on the ecosystem services concept using Q methodology. Ecol. Econ. 2017, 136, 255-265. [CrossRef]

37. Q Method. Available online: http://schmolck.org/qmethod/downpqwin.htm (accessed on 1 November 2019). 
38. Kraak, V.I.; Swinburn, B.; Lawrence, M.; Harrison, P. A Q methodology study of stakeholders' views about accountability for promoting healthy food environments in England through the Responsibility Deal Food Network. Food Policy 2014, 49, 207-218. [CrossRef]

39. Andrews, L.; Drennan, J.; Russell-Bennett, R. Linking perceived value of mobile marketing with the experiential consumption of mobile phones. Eur. J. Mark. 2012, 46, 357-386. [CrossRef]

40. Phi, D.; Dredge, D.; Whitford, M. Understanding conflicting perspectives in event planning and management using Q method. Tour. Manag. 2014, 40, 406-415. [CrossRef]

41. Griffiths, I.; Sharpley, R. Influences of nationalism on tourist-host relationships. Ann. Tour. Res. 2012, 39, 2051-2072. [CrossRef]

42. Graph Pad prism 9.0 (free trial). Available online: https://www.graphpad.com/ (accessed on 19 February 2021).

43. Visme. Available online: www.visme.co (accessed on 19 February 2021).

44. Havlikova, M. Likert scale versus Q-table measures-a comparison of host community perceptions of a film festival. Scand. J. Hosp. Tour. 2016, 16, 196-207. [CrossRef]

45. Carr, L.M.; Liu, D.Y. Measuring stakeholder perspectives on environmental and community stability in a tourism-dependent economy. Int. J. Tour. Res. 2016, 18, 620-632. [CrossRef]

46. Cuppen, E.; Bosch-Rekveldt, M.G.; Pikaar, E.; Mehos, D.C. Stakeholder engagement in large-scale energy infrastructure projects: Revealing perspectives using Q methodology. Int. J. Proj. Manag. 2016, 34, 1347-1359. [CrossRef]

47. Rajé, F. Using Q methodology develop more perceptive insights on transport and social inclusion. Transp. Policy 2007, 14, 467-477. [CrossRef]

48. Babcock-Lumish, J.L. Venture capital decision-making and the culture of risk; an application of Q methodology to US an UK innovations clusters. Compet. Chang. 2005, 9, 329-356. [CrossRef]

49. Thomas, D.M.; Watson, R.T. Q—sorting and mis research: A primer. Commun. Assoc. Inf. Syst. 2002, 8, 141156. Available online: http:/ / www.terry.uga.edu/ \{\}dominict/Thomas\%20and\%20Watson\%20CAIS\%202001.pdf. (accessed on 19 February 2021). [CrossRef]

50. Armatas, C.A.; Venn, T.J.; Watson, A.E. Applying Q-methodology to select and define attributes for non-market valuation: A case study from Northwest Wyoming, United States. Ecol. Econ. 2014, 107, 447-456. [CrossRef]

51. Brewer, G.; Sheldan, S.C.; Facer, R.L., II. Individual conceptions of public service motivation. Public Adm. Rev. 2000, 60, 254-264. [CrossRef]

52. Tractinsky, N.; Jarvenpaa, S.L. Information systems design decisions in a global versus domestic context. MIS Q. 1995, 19, 507-534. [CrossRef]

53. Gabor, M.R. Practical examples concerning application of the $\mathrm{Q}$ factor analysis for marketing data. Analele Universităţii din Oradea. Seria Ştiinţe Economice 2008, XVII, 866-870.

54. Gabor, M.R. Q-methodology (Q factor analysis)—particularities and theoretical considerations for marketing data. Int. J. Arts Commer. 2013, 2, 116-126.

55. Sy, M.M.; Rey-Valette, H.; Simier, M.; Pasqualini, V.; Figuieres, C.; De Wit, R. Identyfying consensus on Coastal Lagoons Ecosystem services and conservation priorities for an effective decision making: A Q approach. Ecol. Econ. 2018, 154, 1-13. [CrossRef]

56. Kornevs, M.; Hauge, J.B.; Meijer, S. Perceptions of stakeholders in project procurement for road construction. Cogent Bus. Manag. 2018, 5, 1520447. [CrossRef] 